\title{
Open- and Closed-System Characteristics of a Tilted Plutonic System, Klamath Mountains, California
}

\author{
Calvin G. Barnes \\ Department of Geosciences, Texas Tech University, Lubbock \\ Charlotte M. Allen \\ Department of Geological Sciences, Virginia Polytechnic Institute and State University, Blacksburg \\ JASON B. SALEEBY \\ Division of Geological and Planetary Sciences, California Institute of Technology, Pasadena
}

\begin{abstract}
The Wooley Creek batholith and Slinkard pluton are adjacent plutons with identical U-Pb zircon ages of $161+4 /-2 \mathrm{Ma}$. The plutons dip toward each other, which suggests that they are connected in the subsurface. Geologic and thermochemical evidence shows that the Slinkard pluton is the structurally lowest part of the system and the Wooley Creek batholith the structurally highest, with a total structural relief of at least $15 \mathrm{~km}$. The wall rocks adjacent to the highest level of the Wooley Creek batholith are intruded by mafic to felsic dikes derived from the subjacent pluton. The Slinkard pluton is predominantly quartz diorite but grades from two-pyroxene diorite to sparse muscovite-biotite granite and shows little evidence of contamination except near contacts. The Wooley Creek batholith grades upward from two-pyroxene gabbro to biotite-hornblende granite and has a central zone in which injected mafic magma was trapped and mixed. Major and trace element data are consistent with closed-system fractionation of the Slinkard pluton and lower (adjacent) Wooley Creek batholith, but with open-system differentiation of the upper Wooley Creek batholith and roof-zone dikes. Andesitic roof-zone dikes show trace element enrichment similar to the central mixed zone of the Wooley Creek batholith and may have differentiated at that central level of the system.
\end{abstract}

\section{INTRODUCTION}

Numerous recent field, geochemical, and petrologic studies have shown that magma mixing is an important process in the evolution of volcanic rocks. One can infer from such studies that many, if not all, long-lived magmatic systems evolve through complex interactions between slowly cooled magmas fractionating in crustal reservoirs and hot, mantle-derived magmas. Evidence of such interactions should also be present in plutonic environments, even if modified by slow cooling and late-stage hydrothermal events. Such evidence was summarized by McBirney [1980] and includes synplutonic dikes [Roddick and Armstrong, 1959], mafic microgranular enclaves [Didier, 1972; Vernon, 1983], and amoeboid to cuspate mafic "pillows" [e.g., Reid et al., 1983; Wiebe, 1980, 1984]. Mafic microgranular enclaves have also been interpreted as restite, refractory residuum from a partial melting event that was carried upward with the ascending granitoid magma [e.g., Presnall and Bateman, 1973; White and Chappell, 1977; Bateman and Nokleberg, 1978]. Knowledge of the vertical distribution of mafic enclaves and their relation, if any, to synplutonic dikes greatly assists in interpreting the origin of the enclaves. However, erosion has rarely exposed sufficient vertical relief in plutonic systems to allow such evaluation [e.g., Taylor, 1976; summary in Pitcher and Bussell, 1985]. The Wooley Creek batholith and Slinkard pluton are part of a vertically and laterally extensive tilted Jurassic calc-alkaline magma system. Both field and geochemical studies suggest that magma mixing played an important role in part of the system, but had little or no effect in other parts. The purpose of this paper is to present field, petrographic, and chronologic evidence for the

Copyright 1986 by the American Geophysical Union.

Paper number 4B5342.

0148-0227/86/004B-5342\$05.00 correlation of the two plutons and for influx of mafic magmas into the plutonic system. We will also show that the system vented magmas as roof-zone dikes through much of its history. The sequel will compare the compositions of the roofzone dikes with those of the underlying batholith and will suggest possible petrologic models for the system.

\section{Geologic Setting}

The accompanying paper [Barnes et al, this issue] describes the regional geologic setting of the Wooley Creek batholith and Slinkard pluton (hereafter WCB/SP). The WCB/SP was intruded into a Triassic and Jurassic accretionary complex (TrPz, Figure 1) at about $161 \mathrm{Ma}$ (see below). Later Nevadan tectonic activity thrust the $\mathrm{TrPz}$ and associated plutons westward (?) over rocks of the western Jurassic belt (Jg in Figure 1 [Saleeby et al., 1982; Jachens et al., 1985]). Subsequent domal uplift raised the structural equivalent of the western Jurassic belt, the Condrey Mountain Schist (CMS, Figure 1), and tilted the overlying $\operatorname{TrPz}$ (and plutons) radially away from the dome [Barnes et al., this issue; Mortimer and Coleman, 1985].

Pressure estimates of contact metamorphic conditions adjacent to the WCB range from $300 \mathrm{MPa}(3 \mathrm{kbar})$ at the southern end to $650 \mathrm{MPa}(6.5 \mathrm{kbar})$ at the northern end and are in accord with uplift centered near the CMS [Barnes et al., this issue]. No pressure estimates of contact metamorphism adjacent to the SP are available; however, granodiorite in the SP contains magmatic epidote [Barnes et al., this issue] that suggests emplacement at pressures greater than $650 \mathrm{MPa}[Z e n$ and Hammarstrom, 1984; Zen, 1985]. The pressure estimates suggest that approximately $9 \mathrm{~km}$ of structural relief are exposed from SW to NE across the WCB and as much as $15 \mathrm{~km}$ across the entire WCB/SP system [Barnes et al., this issue]. Figure 2 shows two cross sections through the system and the inferred pretilting geometry of each section. 


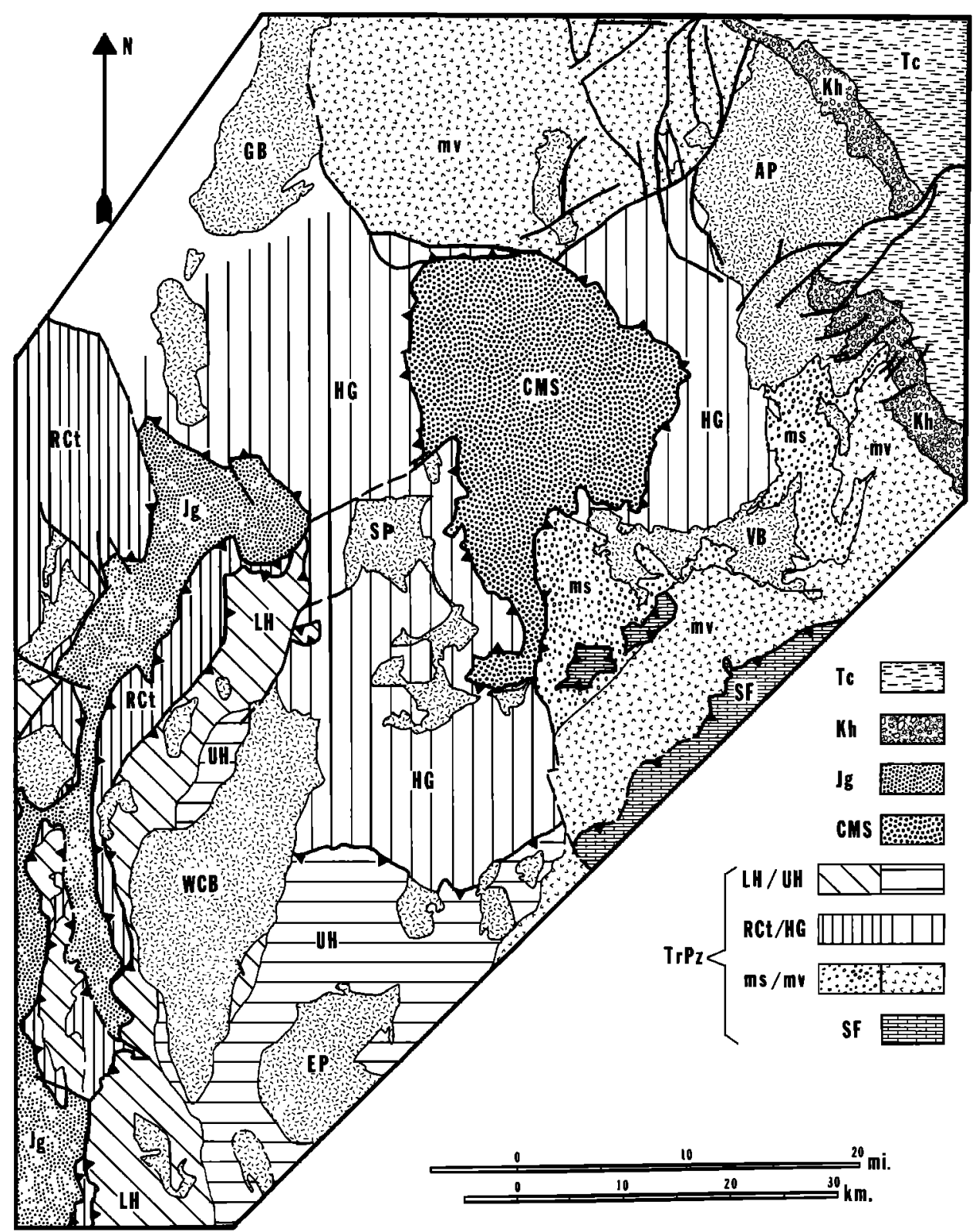

Fig. 1. Generalized geologic map of the central Klamath Mountains of California and Oregon, after Wagner and Saucedo [1985]. CMS, Condrey Mountain Schist; Jg, Jurassic Galice Formation; Kh and Tc are superjacent Cretaceous Hornbrook Formation and Tertiary Colestin Formation, respectively. Western Paleozoic and Triassic belt (TrPz) rocks subdivided into Stuart Fork Formation (SF), undivided metasedimentary (ms) and metavolcanic (mv) rocks, Rattlesnake Creek terrane (RCt) and correlative high-grade melange (HG; Rawson and Petersen [1982]), lower Hayfork (LH) and upper Hayfork (UH) terranes. LH and UH are informal units and are approximately equivalent to the western and eastern Hayfork terranes, respectively, as defined by Wright [1982]. Labeled plutons are Wooley Creek batholith (WCB), Slinkard pluton (SP), English Peak pluton (EP), Vesa Bluffs pluton (VB), Ashland pluton (AP), and Greyback pluton (GB).

\section{Slinkard Pluton}

The Slinkard pluton is the structurally lowest part of the system, is roughly sill-like, and dips away from the Condrey Mountain window. The pluton widens in the north part of the outcrop area, where the basal diorite is capped by granodioritic to granitic rocks (Figure 2). The bulbous outcrop pattern in the southwestern part of the pluton is a reflection of topographic control of the outcrop pattern by deeply incised streams [Allen, 1981].

Protoclastic foliation is typical of the southwestern part of the pluton. This foliation is subparallel to the upper (western) contact and dips toward the WCB (Figure 2). Mylonitic foli- ation is typical of the northern part of the lower contact, where the contact has been modified by minor thrusting (Figures 1 and 2). Foliation in the interior of the pluton is weak or absent.

The pluton shows gradational compositional zonation from structurally lower diorite and quartz diorite to structurally higher tonalite, granodiorite, and rare granite. Sparse latestage aplitic and pegmatitic dikes are most abundant in the structurally highest part of the pluton.

The Slinkard pluton shows little evidence of chemical interaction with its host rocks. However, contacts between the pluton and host peridotite show complex interaction especially along the southeastern contact, where the pluton in- 


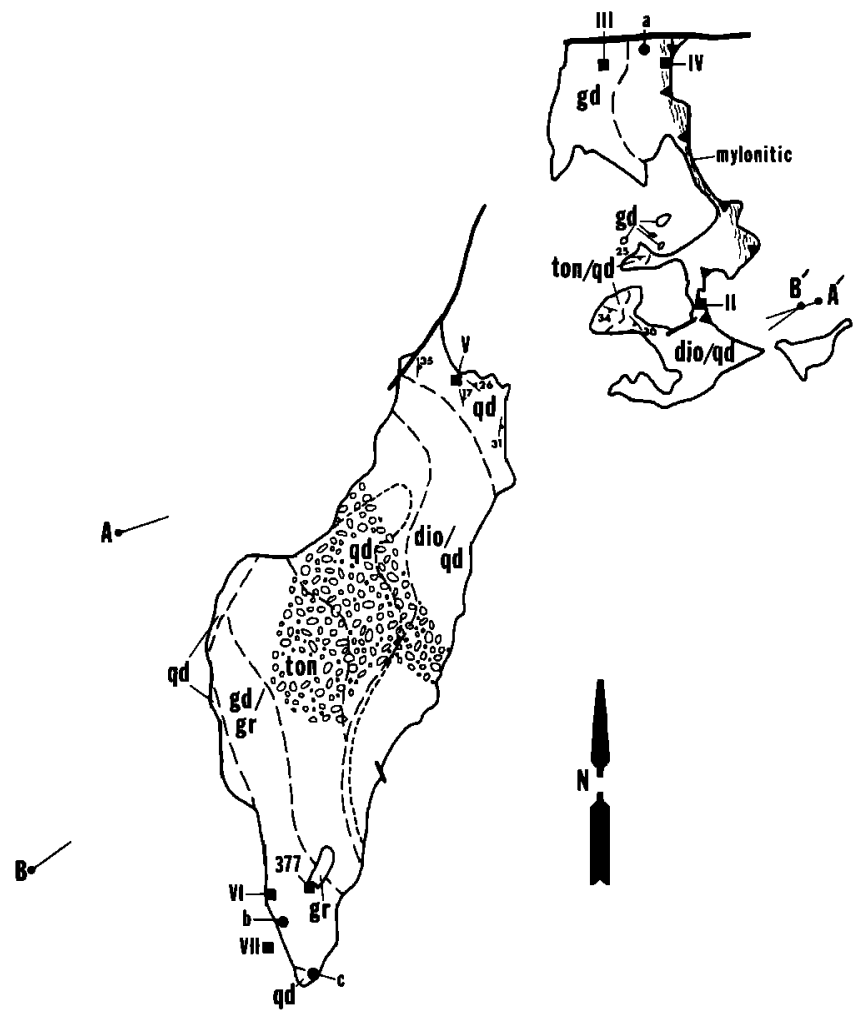

Fig. $2 a$

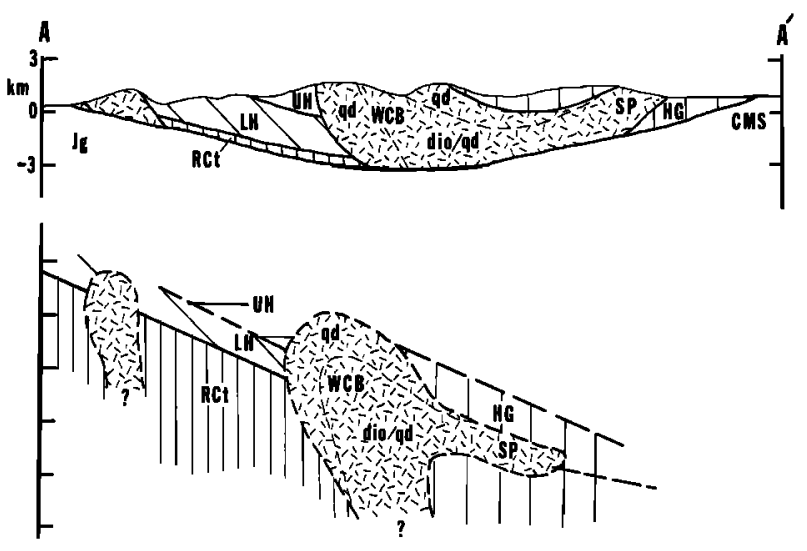

Fig. $2 b$

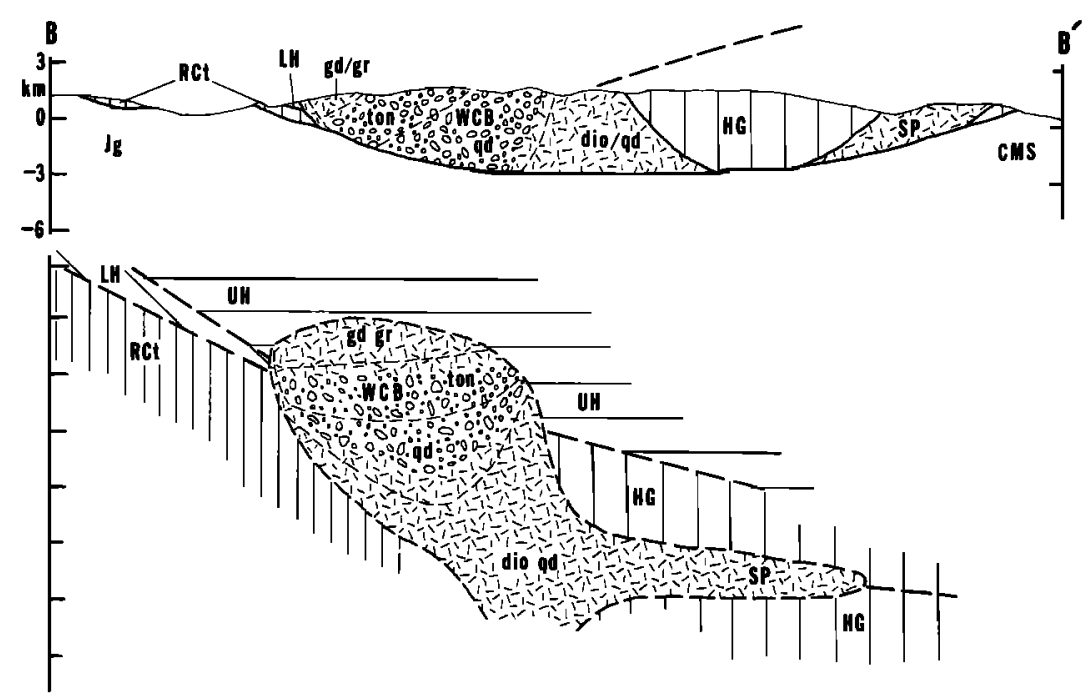

Fig. $2 c$

Fig. 2. (a) Compositional zonation of the WCB/SP system. Long-dashed lines indicate gradational contacts, shortdashed line separates pyroxene-bearing (NE) from pyroxene-free (SW) parts of system. Here, dio is diorite and minor gabbro; qd, quartz diorite; ton, tonalite; gd, granodiorite; and gr, granite. Roof-zone selvages (qd) range from gabbro to tonalite and are predominantly quartz diorite and diorite. Squares show location of samples dated by $\mathrm{Pb}-\mathrm{U}$ techniques; circles show location of samples dated by K-Ar (Lanphere et al. [1968]; $a=66 \mathrm{CLe25}, b=66 \mathrm{CLe21}, c=66 \mathrm{CLe20}$ ). Patterned area in central WCB shows zone that contains abundant mafic enclaves; also note "inward dipping" protoclastic foliation in northeast WCB and southwest SP. See Barnes [1983] and Donato et al. [1982] for further structural information for WCB. (b) and (c) Cross sections of the WCB/SP system and inferred pretilt geometry. Units as in Figure 1, no vertical exaggeration. Note sill-like shape of southern Slinkard pluton. Figure $2 b$ shows correlative nature of RCt and HG and suggests that the northern Wooley Creek batholith intruded a high-angle fault with down-to-west displacement.

truded metaserpentinite with regional metamorphic assemblage of olivine-orthopyroxene-chlorite-spinel. The metaserpentinite reacted with the magma to form a blocky olivine pyroxenite in which pyroxenite blocks are surrounded by a trondhjemitic matrix that locally coalesced to form thin dikes.
Xenoliths of blocky pyroxenite are locally abundant near the contact of the Slinkard, and are typically surrounded by trondhjemite. Amphibolitic xenoliths are also abundant near contacts; however, both xenoliths and microgranitoid enclaves (see below) are sparse in the interior of the pluton. 


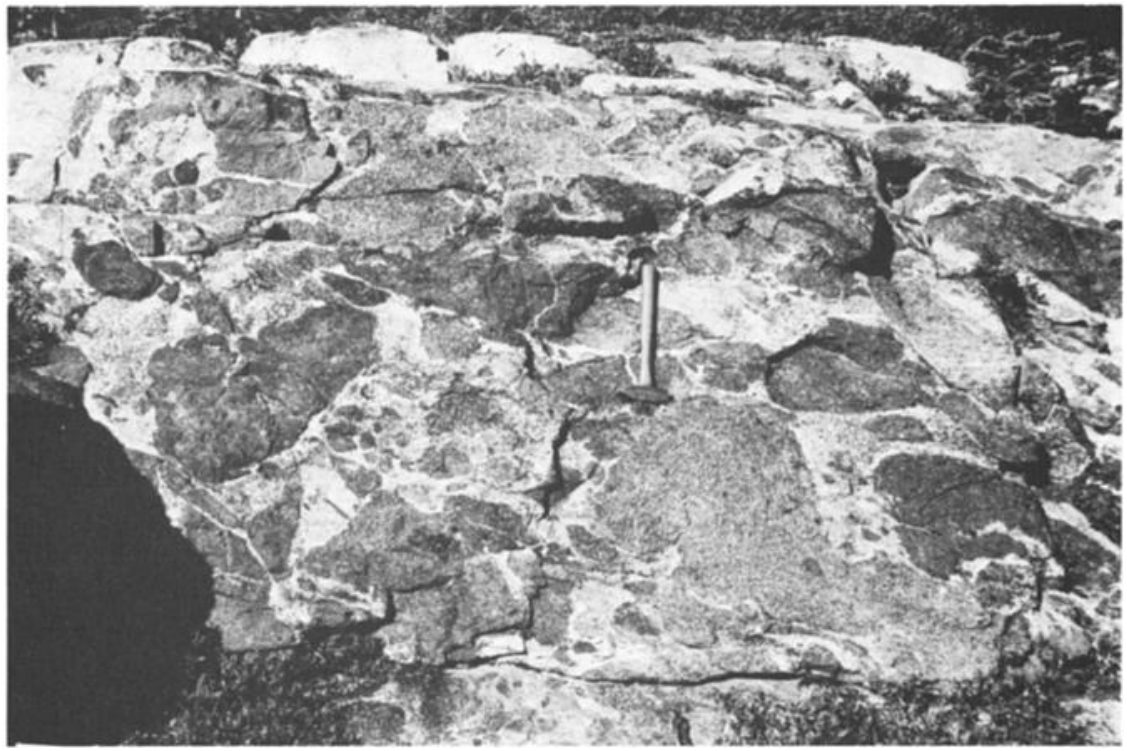

Fig. $3 a$

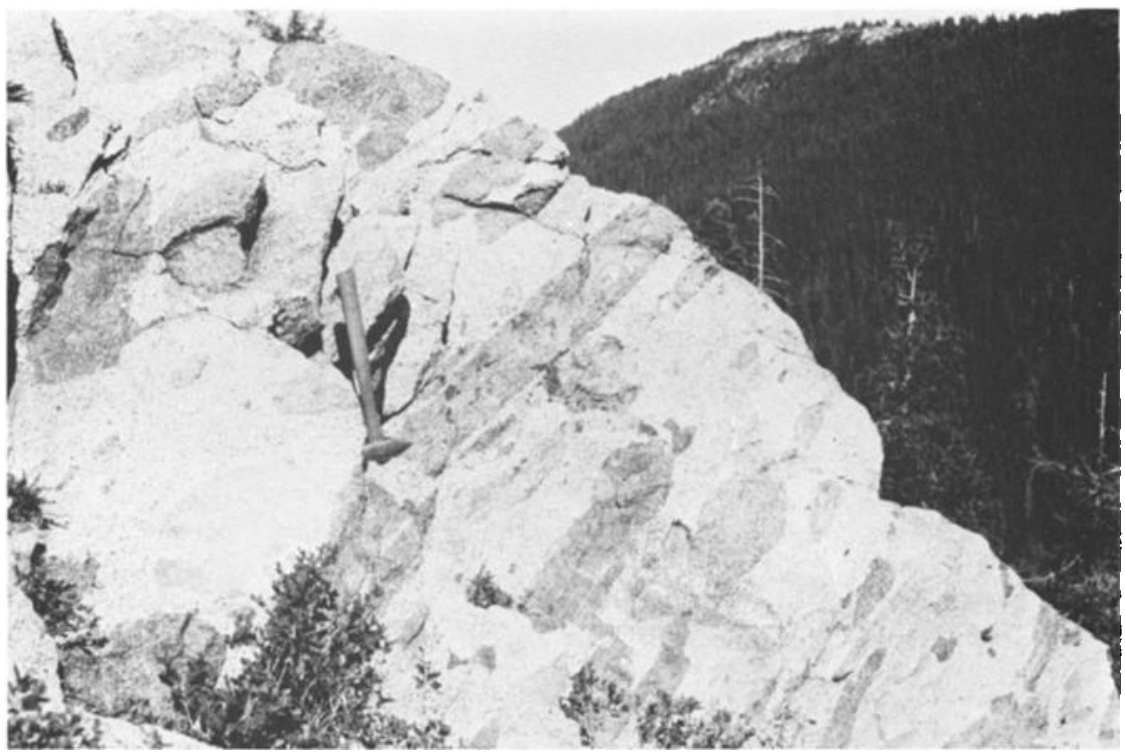

Fig. $3 b$

Fig. 3. Swarm of (a) fusiform and $(b)$ tabular mafic microgranitoid enclaves in the central zone of the Wooley Creek batholith.

\section{Wooley Creek Batholith}

The lower (northeastern) part of the WCB is cylindrical and dips approximately $\mathrm{N} 30^{\circ} \mathrm{E}$, toward the SP (Figure 2 [Barnes, 1983]). The northeastern contact is characterized by NE dipping protoclastic foliation subparallel to the contact and by elongate xenoliths of the host amphibolite. The inward dipping foliations and the similarity in rock type between the northeastern Wooley Creek batholith and the southwestern Slinkard pluton suggest that the two plutons are connected in the subsurface. The WCB is gradationally zoned upward from two-pyroxene diorite and gabbro to biotite hornblende granodiorite and granite (Figure 2 [Barnes, 1983]). The pluton also changes shape from the lower cylindrical body to an upper sill-like mass elongate to the south [Barnes, 1983].

Structurally, intermediate levels of the Wooley Creek batholith are characterized by an abundance of mafic micrograni- toid enclaves and mafic dikes and by the transition from lower pyroxene-bearing rocks to upper pyroxene-free rocks (Figure 2 ; [Barnes, 1983]). The enclaves range in size from $<1 \mathrm{~cm}$ in diameter to at least $10 \mathrm{~m}$ in longest dimension, and in shape from rounded, fusiform bodies, to bulbous equant blobs ("pillows"), to tabular slabs (Figure 3). In rare instances, fusiform enclaves grade into schlieren. The enclaves are typically dispersed, but locally they form swarms of pillows or of fusiform and tabular enclaves. The fusiform and tabular enclaves are invariably aligned parallel to flow foliation in the host. Mafic microgranitoid enclaves are rare below the zone shown in Figure 2; however, we know of no enclave-free outcrop of the Wooley Creek batholith above the zone.

The lower parts of the enclave-rich zone also have abundant mafic dikes. These dikes range from $<3 \mathrm{~cm}$ wide to at least 30 $m$ wide. They range in composition from basaltic to andesitic (rare) and are typically net veined. Some dikes have dark, 


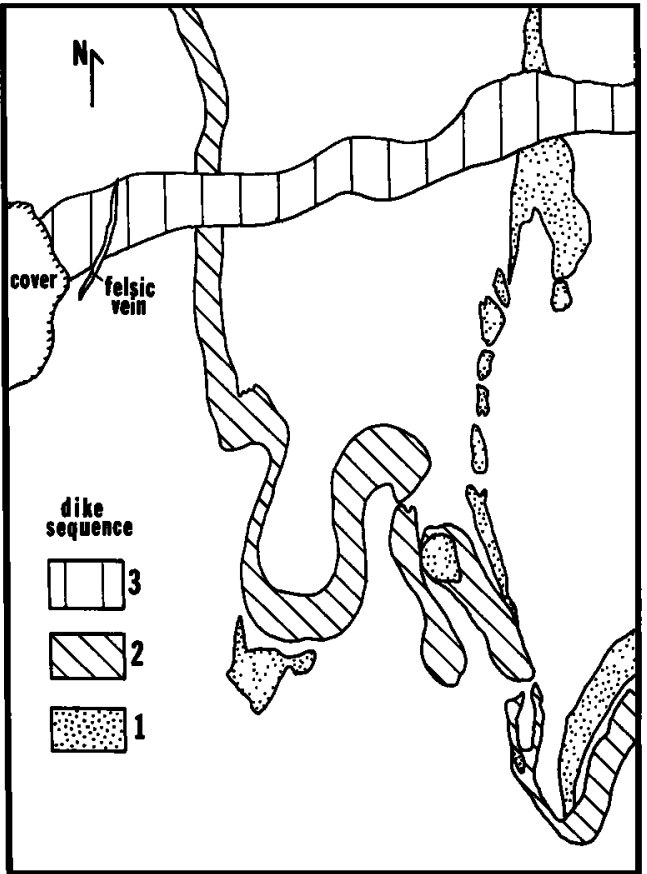

Fig. 4a. Field sketch showing sequence of intrusion and deformation of mafic dikes in the mixed zone of the Wooley Creek batholith. Dike 3 averages $1 \mathrm{~m}$ in width. Earliest dike shows greatest amount of disruption and was locally engulfed by second dike, which is one way in which double enclaves can form. Felsic vein cuts third dike and is biotite-hornblende tonalite; host is foliated pyroxenebiotite-hornblende quartz diorite. Attitude of foliation is approximately N5E, 85E.

fine-grained rims that are suggestive of rapidly cooled margins. We hesitate to ascribe his feature to quenching owing to the nearly ubiquitous occurrence of adjacent veins that are most felsic than the host. It seems likely that mafic constituents from the host have been incorporated into the dike margins during slow cooling with the resultant apparent "quench margin"/felsic vein pair.

Mafic dikes within the pluton commonly show deformation due to flow of the host magma (Figure 4). Dikes intruded at high angles to flow foliation are folded and, in some cases, broken (Figure 4a). Many show cuspate or crenulate contacts with the host. Dikes intruded parallel to foliation show boudinage structure that grades locally into rotated angular blocks (Figure $4 b$ ), an indication of differential strain along the length of the dike.

The southwestern contact zone is characterized by numerous mafic to intermediate dikes. These dikes strike from north to west and typically have intermediate to steep dips. North striking dikes commonly show the effects of regional greenschist-facies metamorphism, whereas west striking dikes do not. Small metamorphosed plutons west of the Wooley Creek batholith (Figure 1) range in composition from basaltic to andesitic and are chemically and petrographically similar to the north striking dikes. We consider the metamorphosed plutons and dikes to be part of an earlier intrusive event. None of the north striking dikes cross cut the Wooley Creek batholith. The WNW striking dikes span a compositional range from fine-grained two-pyroxene microgabbro, to porphyritic twopyroxene andesite, to strongly porphyritic biotite hornblende dacite (see below). We will refer to the WNW striking dikes as "roof-zone dikes" and to the southwestern contact as the "roof zone."

Figure $5 a$ shows a geologic map of the southwestern contact zone. Note that the Wooley Creek batholith does not have a uniform composition near the contact. Instead, zones or selvages that range from gabbro to quartz diorite are common (see below). These zones are typically truncated by, but locally are gradational into, granodiorite and granite that constitute the bulk of the upper part of the pluton. This feature suggests that the original magma that occupied the upper part of the chamber was of dioritic or quartz dioritic composition and that the Wooley Creek batholith magma was not significantly zoned at the time of emplacement.

Figures $5 a$ and $5 b$ also show the cross-cutting relationships between the roof-zone dikes and the pluton as exposed in stream canyons and road cuts. These relationships have allowed us to determine the sequence in which magmas were vented from the system, which in turn, permit us to infer the magmatic history of the WCB/SP (summarized in Table 1). The first three stages of intrusion are from basalt to two-

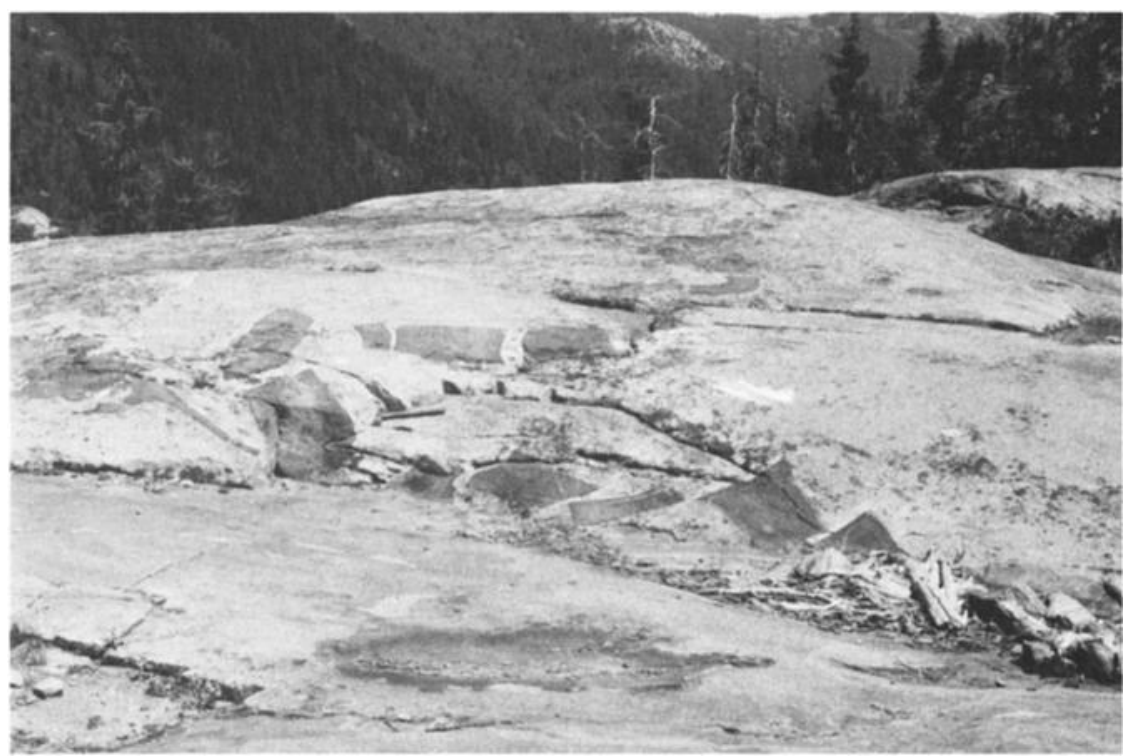

Fig. 4b. Folded, broken, net-veined dike in the Wooley Creek batholith. Hammer handle is parallel to strike of foliation in host. 


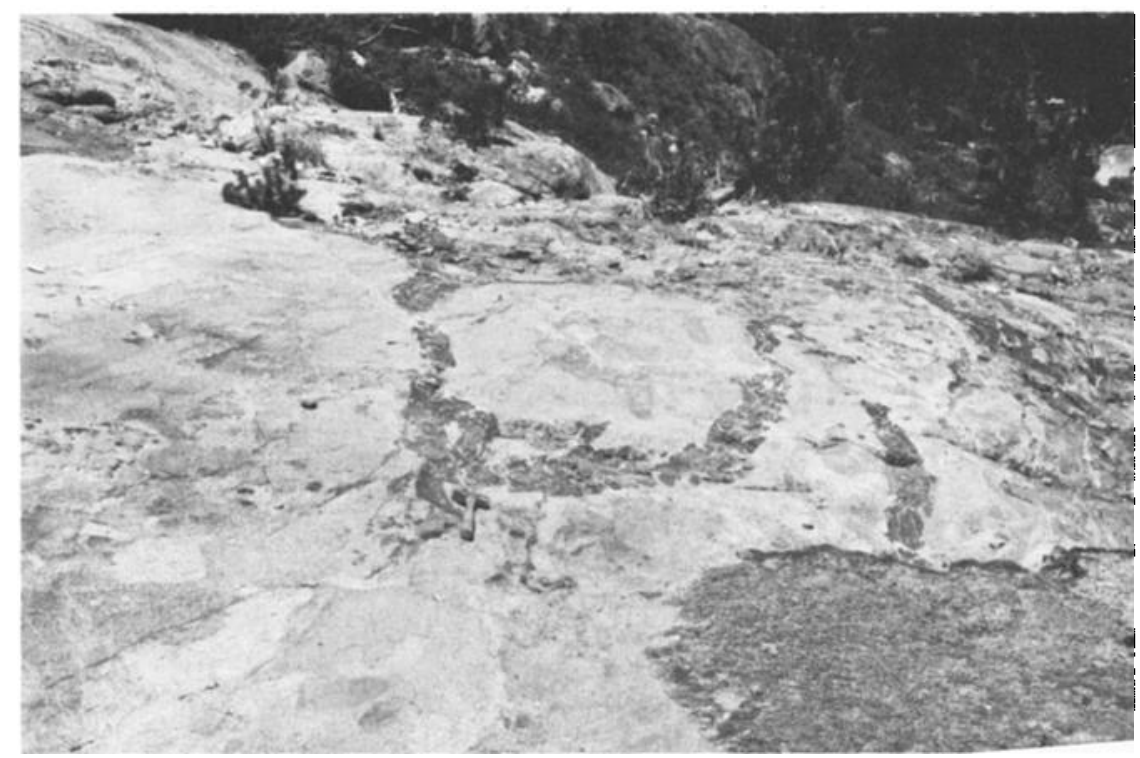

Fig. 4c. Folded and boudinaged dike in Wooley Creek batholith. Note earlier disrupted dike left of the fold nose. Hammer handle parallel to foliation.

pyroxene andesite to hornblende dacite (Figure $5 b$ ). These relationships have been observed in numerous outcrops in the roof zone. Following, or synchronous with, intrusion of the dacitic dikes, granodioritic magma stoped upward and began to crystallize against the upper contact. Pegmatite veins and dikes were emplaced at the end of crystallization of the granodioritic magma. These events were followed by intrusion of late-stage andesitic dikes that include both two-pyroxene andesite that is petrographically identical to early andesitic dikes and hornblende andesite that is unique to late-stage events. Both rock types are restricted in areal extent to the roof zone. The late-stage andesitic dikes cut marginal granodiorite of the WCB and early pegmatite dikes. These andesitic dikes are in turn cut by late-stage pegmatite and aplite. The restriction of the late andesitic dikes to the structurally highest levels of the WCB and the fact that late-stage pegmatite and aplite dikes cut all phases of the plutonic complex (including the late andesites) suggest that magma of intermediate composition was present deeper in the system after the capping granodiorite had solidified.

\section{Radiometric Age Determinations}

Major phases of the WCB/SP system, including a dacitic roof-zone dike, were sampled for $\mathrm{U}-\mathrm{Pb}$ zircon age determinations. The zircon age data along with information on analytical techniques and uncertainties are given in Table 2 . The field locations of the zircon samples are shown in Figure 2, and details on sample setting, petrography, and zircon yield are given in Table 3.

$\mathrm{U}-\mathrm{Pb}$ ages cluster strongly around $161 \pm 2 \mathrm{Ma}$ except for sample VI, in which ages of four fractions are dispersed over a $10 \mathrm{~m} . \mathrm{y}$. range and indicate a disturbance of the isotopic system. An apparent nondisturbed age of $162 \pm 2 \mathrm{Ma}$ was derived for sample VI by mechanical abrasion techniques'(see below). Within analytical uncertainty, ${ }^{207} \mathrm{~Pb} /{ }^{206} \mathrm{~Pb}$ ages derived for the entire sample suite tend to agree with the strong cluster of $\mathrm{U}-\mathrm{Pb}$ ages. Igneous age assignments derived from zircon isotopic data are often based on the concordance or equivalence of the $\mathrm{U}-\mathrm{Pb}$ and $\mathrm{Pb}-\mathrm{Pb}$ ages in a given analysis. Such concordance is arrived at statistically by the overlap of the analytical uncertainties of the constituent ages. On a
${ }^{206} \mathrm{~Pb} /{ }^{238} \mathrm{U}-{ }^{207} \mathrm{~Pb} /{ }^{238} \mathrm{U}$ concordia diagram [Wetherill, 1956], such overlap is exhibited by the error polygon of a given analysis intersecting the concordia line. The overall concordance of ages in the WCB/SP sample suite and the concordance between multiple fractions in samples II, IV, and V suggest very strongly that all phases of the system crystallized within a time span encompassed by the analytical uncertainty of the zircon ages.

The age and overall uncertainty for the WCB/SP system are expressed as $161+4 /-2 \mathrm{Ma}$. The uncertainty based solely on the $\mathrm{U}-\mathrm{Pb}$ ages is $\pm 2 \mathrm{Ma}$. The $+4 \mathrm{Ma}$ uncertainty considers the total body of ${ }^{207} \mathrm{~Pb} /{ }^{206} \mathrm{~Pb}$ age data and the possibility that zircon ages from the entire sample suite have been slightly disturbed from an igneous age as old as $165 \mathrm{Ma}$.

A major problem in the interpretation of all mid-Paleozoic and younger zircon ages is the near linearity of lower concordia. Such linearity could allow the disturbance of the zircon isotopic system to be topologically expressed by downward migration of the error polygon without a resolvable divergence from the concordia line. A downward migration pattern essentially colinear with concordia is seen in sample VI, where ${ }^{206} \mathrm{~Pb} /{ }^{238} \mathrm{U}$ ages for four analyses are dispersed between 161.5 and 151.0 Ma (Figure 6). Downward migration of the sample VI array is a function of decreasing grain size and increasing $U$ concentration (Table 2). Such a relation in normal discordance is a well-documented phenomenon [Silver, 1964; Saleeby and Sharp, 1980]. In an attempt to minimize the effects of $\mathrm{Pb}$ loss from grain margin domains, the coarser $(120-165 \mu)$ fraction was mechanically abraded by techniques similar to Krogh [1982], and resieved to a 80- to $120-\mu$ size class. This artificial size class consisted entirely of clear, well-rounded core-area grain remnants. Its isotopic ages are virtually perfectly concordant at $162 \mathrm{Ma}$. These data are taken to indicate that the natural population underwent $\mathrm{Pb}$ loss (or $\mathrm{U}$ gain) from grain margin domains in which smaller, $\mathrm{U}$-enriched grains underwent greater disturbance.

Hornblende and biotite $\mathrm{K} / \mathrm{Ar}$ ages were determined for the WCB/SP system by Lanphere et al. [1968]. These ages range from $156 \pm 5 \mathrm{Ma}$ to $158 \pm 5 \mathrm{Ma}$, with the exception of a biotite sample from the Slinkard pluton (Figure 2) that yielded an age of $151 \pm 5 \mathrm{Ma}$. All $\mathrm{K}$-Ar ages have been recalculated 


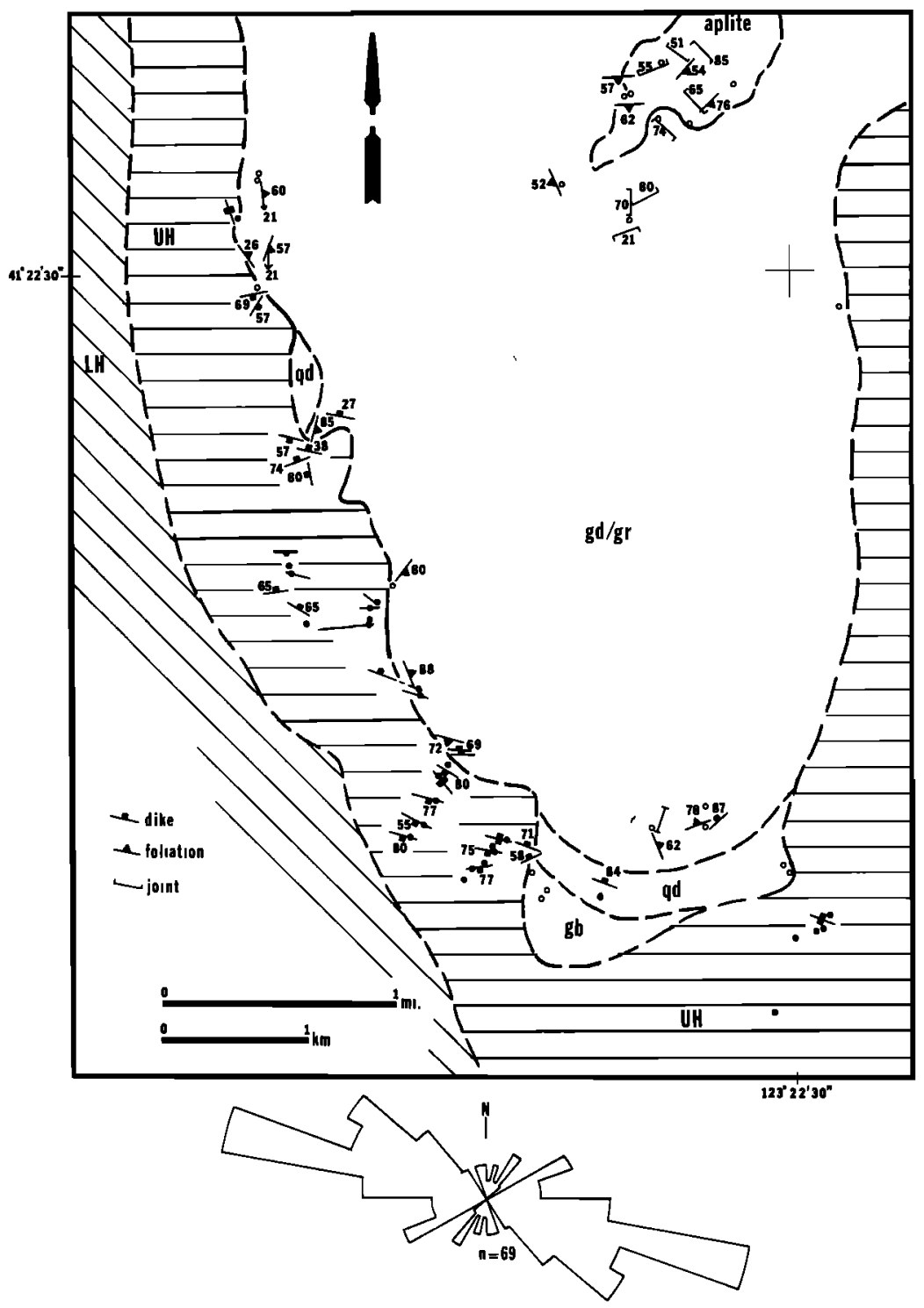

Fig. 5a. Geologic map of the southwestern (roof zone) contact of the Wooley Creek batholith. Note mafic selvages intruded by granodiorite, which was in turn intruded by late-stage andesitic dikes. Rose diagram shows predominant N75W strike of roof-zone dikes.

using the International Union of Geological Sciences recommended decay constants [Steiger and Jager, 1977].

The great depth of emplacement ( $>20 \mathrm{~km}$ for the deepest part of the system; Barnes et al. [this issue]), the proximity of the system to a regional thrust fault (Figure 2), and the younger (151 Ma) biotite age for the Slinkard pluton suggest the possibility that slow cooling or later thermal events may have reset $\mathbf{K}$-Ar systems in these samples. Grain margin domains of zircon from sample VI may likewise have been disturbed under such conditions.

The agreement of the U-Pb ages for the Wooley Creek batholith, Slinkard pluton, and roof-zone dike supports our correlation of the two plutons. In addition, the precise igneous age of the system provides a bracket for the timing of thrusting events in the Klamath Mountains. The Wooley Creek batholith cuts thrust faults between the Rattlesnake Creek terrane and western Hayfork terrane and between the western Hayfork terrane and eastern Hayfork terrane (terminology of Wright [1982]; see Figure 1). The age of the batholith thus provides a minimum age for these two thrusting events of
$161+4 /-2 \mathrm{Ma}$. Thrusting of the WCB/SP is constrained by zircon age data for younger plutons that cut the basal $\mathrm{TrPz}$ thrust to the north and west of the WCB/SP. These data indicate that the WCB/SP and its wallrock complex were thrust westward between $150 \pm 2$ and $140 \pm 2$ Ma [Saleeby et al., 1982; Saleeby, 1984].

\section{Petrography}

\section{Slinkard Pluton}

Lithologic types in the Slinkard pluton can be divided into eastern mylonitic to protoclastic diorite, central diorite and quartz diorite, western protoclastic tonalite, and northwestern granodiorite and granite. Representative modal analyses of these rock types are given in Table 4 . The eastern mylonitic diorite overlies a minor thrust fault (Figure 2) and is characterized by bent and broken plagioclase crystals with tapered albite twins. Fresh samples show strained, polygonal quartz, clusters of euhedral, elongate, brownish green hornblende, sparse kinked biotite books, and accessory apatite, 


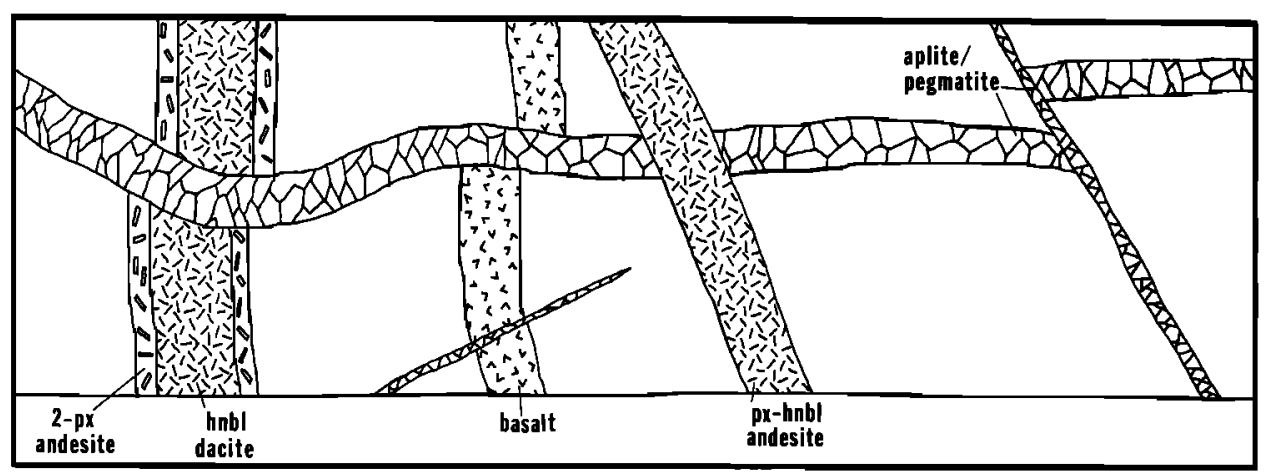

Fig. 5b. Sketch of roof-zone dike cross-cutting relations. Early mafic and andesitic dikes cut by hornblende dacite (e.g., composite dike in this sketch). Horizontal aplite/pegmatite dike cuts previous dikes and is in turn cut by later aplite and by pyroxene-hornblende andesite. Host is chert-argillite breccia of the upper Hayfork terrane (UH). Composite dike is $2 \mathrm{~m}$ wide.

sphene, and zircon. Primary magmatic foliation is formed by planar orientation of plagioclase and brownish green hornblende, whereas foliation due to later deformation is formed by granular blue-green amphibole, smeared, chloritized biotite, and granular epidote.

The central diorite and quartz diorite are heterogeneous on outcrop scale, with considerable outcrop-scale gradational variation in the abundance of quartz and the relative proportions of mafic minerals. Medium-grained flow-foliated hypidiomorphic-granular biotite two-pyroxene diorite occupies the structurally lowest part of this zone. The twopyroxene diorite grades into hornblende diorite and quartz diorite that are characterized by olive to tan subhedral hornblende and bent, euhedral to granular plagioclase with sparse reddish brown biotite. These rock types are similar to the diorite/quartz diorite zone of the WCB (Figure $2 b$ ).

The central diorite/quartz diorite zone is gradational upward to medium-grained foliated protoclastic to hypidiomorphic-granular biotite-hornblende tonalite. Green hornblende and reddish brown biotite are subhedral to anhedral, suggestive of late-stage recrystallization during flow. Identical textural features are present in the nearby quartz diorite zone of the Wooley Creek batholith (Figure 2).

In the northwestern part of the Slinkard pluton, tonalite appears to grade upward to granodiorite and sparse granite. The nature of the contact is uncertain due to poor exposures, but $\mathrm{U}-\mathrm{Pb}$ ages (Table 3 ) show that the dioritic and granodioritic phases of the pluton are of the same or similar age. In addition to the northwestern mass of granodiorite, several smaller granodiorite bodies intrude the roof rocks west of the Slinkard pluton (Figure 2 [Allen, 1981]). These bodies have the same mineralogy and texture as the main mass and suggest that the area is underlain by the SP. The granodiorite/granite is medium to coarse grained, hypidiomorphic granular, and weakly foliated. Reddish brown biotite is the only mafic mineral present. Muscovite is a late-stage constituent in the granitic samples, which also contain quartz with euhedral outlines against poikilitic microcline. Apatite, zircon, and epidote are accessory minerals. The granodiorite/granite is cut by numerous muscovite- and biotite-bearing aplitic dikes (e.g., sample III) that are texturally and mineralogically similar to their host.

\section{Roof-Zone Dikes of the Wooley Creek Batholith}

Roof-zone dikes of the Wooley Creek batholith range from fresh to hydrothermally altered. Alteration is most intense in the fine-grained mafic dikes and is characterized by replacement of mafic phases by actinolitic amphibole and of plagio-

TABLE 1. Summary of Inferred Intrusive and Crystallization Sequence of the WCB/SP System

\begin{tabular}{|c|c|c|}
\hline Order & Roof Zone & Pluton* \\
\hline 1 & $\begin{array}{l}\text { Mafic dikes intrude wall } \\
\text { rocks }\end{array}$ & $\begin{array}{l}\text { Initial intrusive event, } \\
\text { formation of mafic selvages }\end{array}$ \\
\hline 2 & $\begin{array}{l}\text { Two-pyroxene andesite dikes } \\
\text { intrude wall rocks }\end{array}$ & $\begin{array}{l}\text { Formation of interface zone } \\
\text { in Wooley Creek batholith, } \\
\text { magma mixing in interface zone }\end{array}$ \\
\hline 3 & $\begin{array}{l}\text { Dacite dikes intrude wall } \\
\text { rocks }\end{array}$ & $\begin{array}{l}\text { Granodiorite begins to } \\
\text { crystallize and stope upward }\end{array}$ \\
\hline 4 & Early aplite and pegmatite. & Early aplite and pegmatite \\
\hline 5 & $\begin{array}{l}\text { Late two-pyroxene andesite } \\
\text { and pyroxene-hornblende } \\
\text { andesite dikes intrude into } \\
\text { upper granodiorite and wall } \\
\text { rocks }\end{array}$ & $\begin{array}{l}\text { Formation of enclave swarms } \\
\text { in mixed zone of Wooley } \\
\text { Creek batholith }\end{array}$ \\
\hline 6 & $\begin{array}{l}\text { Pegmatite and aplite dikes } \\
\text { intrude wall rocks }\end{array}$ & $\begin{array}{l}\text { Intrusion and deformation of } \\
\text { late mafic dikes, formation } \\
\text { of pegmatites and aplite dikes }\end{array}$ \\
\hline 7 & & $\begin{array}{l}\text { Thrusting, mylonitic } \\
\text { deformation of lower Slinkard } \\
\text { pluton contact }\end{array}$ \\
\hline
\end{tabular}

*Influx of mafic magma probably continued throughout the WCB/SP cooling history. 
TABLE 2. Zircon Isotopic Age Data

\begin{tabular}{|c|c|c|c|c|c|c|c|c|c|c|c|c|c|c|}
\hline \multirow[b]{2}{*}{$\begin{array}{c}\text { Sample } \\
\text { Number }\end{array}$} & \multicolumn{2}{|c|}{$\begin{array}{l}\text { Fraction } \\
\text { Properties }\end{array}$} & \multirow[b]{2}{*}{$\begin{array}{c}\text { Milli- } \\
\text { grams } \\
\text { Analyzed }\end{array}$} & \multirow[b]{2}{*}{$\begin{array}{l}{ }^{238} \mathrm{U} \\
\mathrm{ppm}\end{array}$} & \multirow[b]{2}{*}{$\begin{array}{c}{ }^{206} \mathrm{~Pb} \text {, } \\
\text { ppm } \\
\text { r.g. }\end{array}$} & \multicolumn{3}{|c|}{ Isotopic Composition } & \multicolumn{3}{|c|}{ Radiogenic Ratios } & \multicolumn{3}{|c|}{ Isotopic Ages, $\$ \mathbf{M a}$} \\
\hline & $\begin{array}{l}\text { Magnetic } \\
\text { Properties* }\end{array}$ & $\begin{array}{l}\text { Grain } \\
\text { Size, } \mu\end{array}$ & & & & $\frac{{ }^{206} \mathrm{~Pb}}{{ }^{204} \mathrm{~Pb}}$ & $\frac{{ }^{206} \mathrm{~Pb}}{{ }^{207} \mathrm{~Pb}}$ & $\frac{{ }^{206} \mathrm{~Pb}}{{ }^{208} \mathrm{~Pb}}$ & $\frac{{ }^{206} \mathrm{~Pb}}{{ }^{238} \mathrm{U}}$ & $\frac{{ }^{207} \mathrm{~Pb}}{{ }^{235} \mathrm{U}}$ & $\frac{{ }^{207} \mathrm{~Pb}}{{ }^{206} \mathrm{~Pb}}$ & $\frac{{ }^{206} \mathrm{~Pb}}{{ }^{238} \mathrm{U}}$ & $\frac{{ }^{207} \mathrm{~Pb}}{{ }^{235} \mathrm{U}}$ & $\frac{{ }^{207} \mathrm{~Pb}}{{ }^{206} \mathrm{~Pb}}$ \\
\hline \multicolumn{15}{|c|}{ Slinkard Quartz Diorite } \\
\hline II & $10 / 20$ & $\begin{array}{r}<45 \ddagger \\
45-80 \ddagger\end{array}$ & $\begin{array}{l}3.7 \\
3.9\end{array}$ & $\begin{array}{l}306 \\
191\end{array}$ & $\begin{array}{l}3.7 \\
4.2\end{array}$ & $\begin{array}{l}1353 \\
1367\end{array}$ & $\begin{array}{l}16.60 \\
16.65\end{array}$ & $\begin{array}{l}5.645 \\
5.674\end{array}$ & $\begin{array}{l}0.02500 \\
0.02541\end{array}$ & $\begin{array}{l}0.1704 \\
0.1728\end{array}$ & $\begin{array}{l}0.04939 \\
0.04932\end{array}$ & $\begin{array}{l}159.2 \\
161.8\end{array}$ & $\begin{array}{l}159.8 \\
161.9\end{array}$ & $\begin{array}{l}166 \pm 10 \\
163 \pm 10\end{array}$ \\
\hline III & $10 / 20$ & $<120 \ddagger$ & 4.0 & 1030 & $22.4^{\text {Slir }}$ & $\begin{array}{c}\text { kard } G r \\
2400\end{array}$ & $\begin{array}{c}\text { anodior } \\
17.99\end{array}$ & $\begin{array}{l}\text { te } \\
10.891\end{array}$ & 0.02613 & 0.1723 & 0.04946 & 160.0 & 161.4 & $170 \pm 10$ \\
\hline IV & $10 / 20$ & $\begin{array}{l}45-80 \\
80-120\end{array}$ & $\begin{array}{l}18.2 \\
30.3\end{array}$ & $\begin{array}{l}317 \\
345\end{array}$ & $\begin{array}{l}\text { Slin } \\
6.9 \\
7.6\end{array}$ & $\begin{array}{c}\text { kard Qu } \\
3807 \\
5525\end{array}$ & $\begin{array}{c}\text { artz Dio } \\
18.71 \\
19.23\end{array}$ & $\begin{array}{l}\text {-ite } \\
16.46 \\
14.38\end{array}$ & $\begin{array}{l}0.02529 \\
0.02545\end{array}$ & $\begin{array}{l}0.1728 \\
0.1732\end{array}$ & $\begin{array}{l}0.04959 \\
0.04934\end{array}$ & $\begin{array}{l}161.0 \\
162.0\end{array}$ & $\begin{array}{l}161.9 \\
162.1\end{array}$ & $\begin{array}{l}175 \pm 10 \\
164 \pm 10\end{array}$ \\
\hline $\mathrm{V}$ & $5 / 20$ & $\begin{array}{l}45-80 \\
80-120\end{array}$ & $\begin{array}{l}21.5 \\
26.3\end{array}$ & $\begin{array}{l}362 \\
298\end{array}$ & $\begin{array}{l}\text { Wonole } \\
8.0 \\
6.5\end{array}$ & $\begin{array}{c}\text { Creek } \\
4425 \\
2030\end{array}$ & $\begin{array}{l}\text { Quartz } \\
18.95 \\
17.70\end{array}$ & $\begin{array}{r}\text { Diorite } \\
8.332 \\
7.300\end{array}$ & $\begin{array}{l}0.02553 \\
0.02539\end{array}$ & $\begin{array}{l}0.1740 \\
0.1724\end{array}$ & $\begin{array}{l}0.04945 \\
0.04926\end{array}$ & $\begin{array}{l}162.5 \\
161.7\end{array}$ & $\begin{array}{l}162.9 \\
161.5\end{array}$ & $\begin{array}{l}169 \pm 10 \\
160 \pm 10\end{array}$ \\
\hline VI & $10 / 20$ & $\begin{array}{r}<80 \\
80-120 \\
120-165 \\
120-165\end{array}$ & $\begin{array}{l}22.5 \\
31.4 \\
31.2\end{array}$ & $\begin{array}{r}1025 \\
712 \\
618\end{array}$ & $\begin{array}{l}W \text { Woll } \\
21.0 \\
14.9 \\
13.0\end{array}$ & $\begin{array}{l}y \text { Creek } \\
6220 \\
6625 \\
5397\end{array}$ & $\begin{array}{c}\text { Granod } \\
19.33 \\
19.37 \\
19.25\end{array}$ & $\begin{array}{l}\text { iorite } \\
8.610 \\
9.073 \\
8.657\end{array}$ & $\begin{array}{l}0.02369 \\
0.02418 \\
0.02436\end{array}$ & $\begin{array}{l}0.1612 \\
0.1646 \\
0.1652\end{array}$ & $\begin{array}{l}0.04937 \\
0.04941 \\
0.04923\end{array}$ & $\begin{array}{l}151.0 \\
154.0 \\
155.1\end{array}$ & $\begin{array}{l}151.8 \\
154.8 \\
155.3\end{array}$ & $\begin{array}{l}165 \pm 10 \\
167 \pm 10 \\
158 \pm 10\end{array}$ \\
\hline & & $\rightarrow 80-120 \dagger$ & 7.0 & 431 & 9.5 & 2136 & 17.80 & 8.509 & 0.02536 & 0.1724 & 0.04931 & 161.5 & 161.5 & $162 \pm 10$ \\
\hline \multicolumn{15}{|c|}{ Wooley Creek Dike } \\
\hline
\end{tabular}

Here, r.g. is radiogenic lead.

*Magnetic properties are given as nonmagnetic split at side/front slopes for $1.7 \mathrm{~A}$ on Franz isodynamic separator. Samples hand picked to $99.9 \%$ purity prior to dissolution.

† Grains mechanically abraded to smaller size class by techniques similar to Krogh [1982].

$\ddagger$ Spiked by mixed ${ }^{205} \mathrm{~Pb}^{235} \mathrm{U}$, others aliquoted and spiked by ${ }^{200} \mathrm{~Pb}^{235} \mathrm{U}$. Dissolution and chemical extraction techniques modified from Krogh [1973].

§Decay constants used in age calculations are $\lambda^{238} \mathrm{U}=1.55125 \times 10^{-10}, \lambda^{235} \mathrm{U}=9.8485 \times 10^{-10}[\mathrm{Jaffey}$ et al., 1971$] ;{ }^{238} \mathrm{U} /{ }^{235} \mathrm{U}$ atom $=137.8$ [Chen and Wasserburg, 1981]. Common $\mathrm{Pb}$ compositions used for nonradiogenic correction based on blank determinations are ${ }^{206} \mathrm{~Pb} /{ }^{204} \mathrm{~Pb}=18.6$ and ${ }^{207} \mathrm{~Pb} /{ }^{204} \mathrm{~Pb}=15.6$. Long-term reproducibility used in age uncertainties that slightly exceed effects of mass fractionation, spike uncertainty, counting statistics, and uncertain initial $\mathrm{Pb}$ compositions; uncertainties of $\mathrm{U}-\mathrm{Pb}$ ages $\simeq \pm 1 \%$. Mass spectrometer performance monitored on a regular basis by runs of National Bureau of Standards 983 and U500 standards.

clase by epidote. The descriptions and analyses that follow are of relatively unaltered samples.

Mafic roof-zone dikes range from aphyric to strongly clinopyroxene-phyric. Diabasic to subophitic textures are typical of the aphyric varieties, with granular clinopyroxene (cpx, $\mathrm{Wo}_{40} \mathrm{En}_{49}$ ) and orthopyroxene (opx, $\mathrm{En}_{65}$ ) rimmed by pale brown to olive hornblende. Biotite and opaque minerals are ubiquitous, and interstitial quartz is common. Cpx-phyric varieties contain oscillatory zone augite $\left(\mathrm{Wo}_{38} \mathrm{En}_{45}\right.$ to $\left.\mathrm{Wo}_{41} E_{42}\right)$, normally zoned plagioclase $\left(\mathrm{An}_{\mathrm{B} 7.73}\right)$, and rare iddingsitized olivine. The cpx-phyric dikes are compositionally similar to cpx-rich mafic selvages in the roof zone (Table 5 and Barnes [1983, Table 7]).

Early andesitic dikes contain euhedral phenocrysts of cpx, opx, and plagioclase that average $2 \mathrm{~mm}$ in longest dimension. Clinopyroxene phenocrysts show weak normal and reverse

TABLE 3. Data on Zircon Sample Location, Petrography, and Yield

\begin{tabular}{|c|c|c|c|c|}
\hline Sample & $\begin{array}{l}\text { Field Location } \\
\text { West Longitude } \\
\text { North Latitude }\end{array}$ & Field Setting & Petrography & $\begin{array}{l}\text { Yield, } \sim \mathrm{mg} \\
\text { Zircon } / \mathbf{k g} \\
\text { Sample }\end{array}$ \\
\hline II & $\begin{array}{l}123^{\circ} 06^{\prime} 30^{\prime \prime} \\
45^{\circ} 40^{\prime}\end{array}$ & $\begin{array}{l}\text { Noncataclastic eastern } \\
\text { margin of SP }\end{array}$ & $\begin{array}{l}\text { Foliated biotite-two-pyroxene } \\
\text { quartz diorite }\end{array}$ & $8 / 16$ \\
\hline III & $\begin{array}{r}123^{\circ} 11^{\prime} 30^{\prime \prime} \\
41^{\circ} 47^{\prime} 45^{\prime \prime}\end{array}$ & $\begin{array}{l}\text { Aplitic dike intrusive } \\
\text { into northwestern } \\
\text { granodiorite of SP }\end{array}$ & $\begin{array}{l}\text { Medium-grained, } \\
\text { massive muscovite-biotite } \\
\text { granite with magmatic epidote }\end{array}$ & $5 / 22$ \\
\hline IV & $\begin{array}{r}123^{\circ} 08^{\prime} 15^{\prime \prime} \\
41^{\circ} 49^{\prime} 45^{\prime \prime}\end{array}$ & $\begin{array}{l}\text { Cataclastic eastern } \\
\text { margin of SP }\end{array}$ & $\begin{array}{l}\text { Cataclastic biotite-hornblende } \\
\text { tonalite with secondary } \\
\text { actinolitic amphibole, epidote }\end{array}$ & $700 / 30$ \\
\hline $\mathbf{V}$ & $\begin{array}{r}123^{\circ} 17^{\prime} \\
41^{\circ} 39^{\prime}\end{array}$ & $\begin{array}{l}\text { Marginal quartz diorite } \\
\text { of WCB }\end{array}$ & $\begin{array}{l}\text { Strongly foliated (protoclastic) } \\
\text { biotite-hornblende quartz diorite }\end{array}$ & $400 / 15$ \\
\hline VI & $\begin{array}{l}123^{\circ} 25^{\prime} \\
41^{\circ} 22^{\prime} 30^{\prime \prime}\end{array}$ & $\begin{array}{l}\text { Upper level granodiorite } \\
\text { of WCB }\end{array}$ & $\begin{array}{l}\text { Coarse-grained biotite-hornblende } \\
\text { granodiorite with poikilitic } \\
\text { K-feldspar and sparse mafic enclaves }\end{array}$ & $600 / 23$ \\
\hline VII & $\begin{array}{l}123^{\circ} 24^{\prime} 45^{\prime \prime} \\
41^{\circ} 21^{\prime}\end{array}$ & $\begin{array}{l}\text { Roo[-zone dike of } \\
\text { WCB/SP, intrudes earlier } \\
\text { two-pyroxene andesite } \\
\text { dike }\end{array}$ & $\begin{array}{l}\text { Porphyritic biotite-hornblende } \\
\text { dacite with euhedral quartz } \\
\text { phenocrysts, granular to } \\
\text { granophyric groundmass }\end{array}$ & $800 / 24$ \\
\hline
\end{tabular}




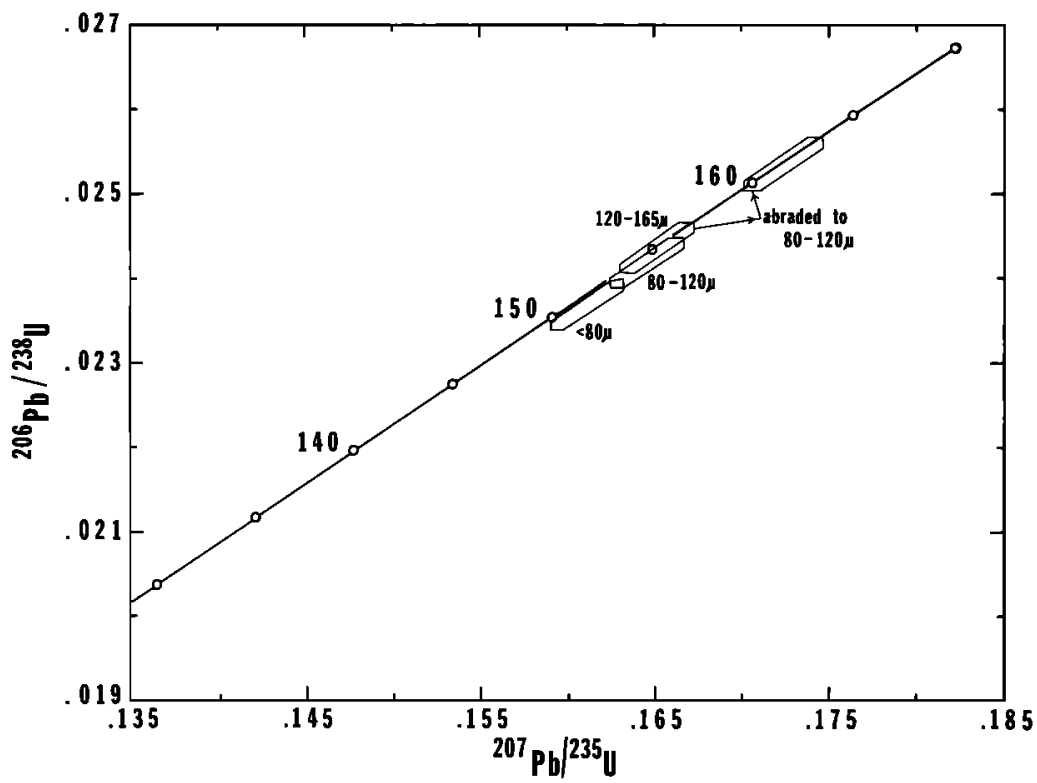

Fig. 6. Concordia plot [after Wetherill, 1956] showing dispersion of sample VI U-Pb ages down concordia line from presumed true age of $162 \mathrm{Ma}$ represented by 120 - to $165-\mu$ fraction mechanically abraded to 80 - to $120-\mu$ size class. Nonabraded size classes shown are from natural population.

zoning and range from $\mathrm{Wo}_{41} \mathrm{En}_{45}$ to $\mathrm{Wo}_{40} \mathrm{En}_{36}$ (Figure 7). Opx phenocrysts range from $\mathrm{En}_{74}$ to $\mathrm{En}_{62}$ and also show normal and reverse zoning. Pyroxene phenocrysts are typically rimmed by olive-brown hornblende. Plagioclase phenocrysts commonly show normally zoned cores and wide, reverse- to oscillatory-zoned rims. Core compositions range from $\mathrm{An}_{66}$ to $\mathrm{An}_{53}$ (Figure 8). The groundmass consists of plagioclase, amphibole, biotite, quartz, alkali feldspar, ilmenite, and magnetite.

Late-stage andesitic dikes fall into two petrographic types: two-pyroxene dikes identical to those described above, and pyroxene-hornblende andesite. The pyroxene-hornblende andesite has sparse phenocrysts of cpx, elongate brown to olive hornblende, and oscillatory-zoned plagioclase. These dikes commonly contain xenocrysts of quartz and/or biotite rimmed by olive hornblende. Groundmass textures range from intergranular to granophyric arrangements of plagioclase, alkali feldspar, quartz, hornblende, and biotite, with accessory apatite and opaque minerals.

Dacitic dikes of the roof zone range in texture from strongly porphyritic to coarse-grained hypidiomorphic granular. Phenocrysts are weakly zoned to unzoned magnesiohornblende, red-brown biotite, oscillatory normal-zoned plagioclase $\left(\mathrm{An}_{53-47}\right.$ cores; Figure 8 ), and quartz. The groundmass consists of hornblende, biotite, plagioclase, alkali feldspar, and quartz, with accessory apatite, zircon, ilmenite, and rare allanite.

\section{Microgranitoid Enclaves and Dikes}

Microgranitoid enclaves and mafic dikes within the Wooley Creek batholith range from porphyritic to equigranular with phenocrysts of hornblende and oscillatory-zoned plagioclase. Acicular apatite is a ubiquitous groundmass phase. Some finegrained enclaves contain 1- to 2-mm-diameter crystals of quartz that are enclosed by a groundmass that lacks quartz. These relations suggest that the coarse-grained quartz crystals and possibly some of the hornblende and plagioclase "phenocrysts" were originally present in the host and were entrained in the enclave when both the enclave and host were in a magmatic state. Such observations are in accord with field evidence for disruption of dikes to form enclave swarms (above). Further evidence that the enclaves crystallized from a magma includes the presence of oscillatory-zoned plagioclase and acicular apatite. Vernon [1983] showed that these features are igneous and do not support derivation of such enclaves from the source region of the host granitoid.

TABLE 4. Representative Modal Analyses of the Slinkard Pluton

\begin{tabular}{|c|c|c|c|c|c|c|c|c|c|}
\hline & \multicolumn{9}{|c|}{ Sample } \\
\hline & II & III & IV & 20 & $60 A$ & $71 \mathrm{~A}$ & $95 \mathrm{~A}$ & $117 \mathrm{~A}$ & $149 \mathrm{~A}$ \\
\hline Plagioclase & 46.7 & 30.8 & 30.0 & 60.7 & 36.2 & 25.5 & 37.4 & 54.5 & 49.8 \\
\hline Quartz & 8.0 & 45.4 & 32.9 & 22.1 & 28.9 & 10.5 & 21.6 & 23.0 & 33.7 \\
\hline Microcline & & 15.9 & & 8.5 & & & & 1.8 & 7.1 \\
\hline Biotite & 2.6 & 5.7 & 6.7 & 8.0 & & & 13.5 & 14.0 & 8.4 \\
\hline $\begin{array}{l}\text { Hornblende } \\
\text { Brown }\end{array}$ & 5.1 & & & & & 64.0 & & & \\
\hline Green & & & 30.3 & & 34.9 & & 27.5 & 6.7 & 1.0 \\
\hline Clinopyroxene & 30.1 & & & & & & & & \\
\hline Orthopyroxene & 7.0 & & & & & & & & \\
\hline Opaque minerals & 0.5 & & & & & & & & \\
\hline Muscovite & & 2.2 & & 0.7 & & & & & \\
\hline Total & 100.0 & 100.0 & 99.9 & 100.0 & 100.0 & 100.0 & 100.0 & 100.0 & 100.0 \\
\hline Specific gravity & 2.96 & 2.65 & 2.81 & 2.66 & 2.91 & 2.97 & 2.83 & 2.74 & 2.65 \\
\hline
\end{tabular}


TABLE 5. Representative Major and Trace Element Analyses for the Slinkard Pluton and WCB Dikes and Enclaves

\begin{tabular}{|c|c|c|c|c|c|c|c|c|c|c|c|c|c|c|c|c|}
\hline Sample & $\mathrm{SiO}_{2}$ & $\mathrm{TiO}_{2}$ & $\mathrm{Al}_{2} \mathrm{O}_{3}$ & $\mathrm{Fe}_{2} \mathrm{O}_{3}$ & $\mathrm{MgO}$ & $\mathrm{MnO}$ & $\mathrm{CaO}$ & $\mathrm{Na}_{2} \mathrm{O}$ & $\mathrm{K}_{2} \mathrm{O}$ & $\mathrm{P}_{2} \mathrm{O}_{5}$ & $\mathbf{H}_{2} \mathbf{O}^{+}$ & $\mathrm{H}_{2} \mathrm{O}^{-}$ & Total & $\begin{array}{c}\text { Rb, } \\
\text { ppm }\end{array}$ & $\begin{array}{c}\text { Sr, } \\
\text { ppm }\end{array}$ & $\begin{array}{c}\mathrm{Zr} \text {, } \\
\text { ppm }\end{array}$ \\
\hline \multicolumn{17}{|c|}{ Slinkard Pluton } \\
\hline II & 53.43 & 0.42 & 16.43 & 8.24 & 7.73 & 0.15 & 10.60 & 2.47 & 0.46 & 0.07 & 0.16 & 0.09 & 100.24 & b.d. & 347 & 13 \\
\hline III* & 77.34 & 0.07 & 13.78 & 1.42 & 0.14 & 0.03 & 1.76 & 4.13 & 2.68 & 0.01 & 0.31 & 0.08 & 101.76 & 73 & 288 & 106 \\
\hline IV & 58.46 & 0.55 & 16.09 & 6.78 & 5.11 & 0.12 & 7.33 & 2.95 & 1.44 & 0.11 & 0.51 & 0.13 & 99.57 & 40 & 338 & 85 \\
\hline $10^{*}$ & 74.94 & 0.05 & 14.26 & 0.21 & b.d. & b.d. & 1.12 & 3.02 & 5.98 & 0.02 & 0.20 & 0.09 & 99.89 & 72 & 255 & 15 \\
\hline $15^{*}$ & 72.28 & 0.00 & 14.50 & 0.08 & b.d. & b.d. & 0.14 & 2.03 & 9.88 & 0.02 & 0.16 & 0.17 & 99.26 & 197 & 39 & 10 \\
\hline 20 & 69.05 & 0.29 & 16.77 & 2.71 & 0.84 & 0.05 & 3.33 & 5.17 & 1.86 & 0.12 & 0.37 & 0.18 & 100.74 & 199 & 409 & 164 \\
\hline $60 A$ & 59.27 & 0.56 & 15.40 & 6.46 & 5.07 & 0.12 & 7.47 & 2.59 & 1.35 & 0.10 & 1.54 & 0.26 & 100.18 & 38 & 248 & 90 \\
\hline $71 \mathrm{~A}$ & 55.14 & 0.27 & 15.15 & 7.30 & 7.24 & 0.15 & 9.79 & 2.35 & 0.78 & 0.09 & 1.58 & 0.20 & 100.05 & 15 & 270 & 39 \\
\hline $95 \mathrm{~A}$ & 58.09 & 0.65 & 15.86 & 6.36 & 6.06 & 0.11 & 7.45 & 2.70 & 1.34 & 0.11 & 0.89 & 0.27 & 99.90 & 32 & 274 & 101 \\
\hline $117 \mathrm{~A}$ & 62.86 & 0.51 & 17.12 & 4.59 & 3.62 & 0.08 & 5.95 & 3.51 & 1.65 & 0.13 & 0.81 & 0.19 & 100.91 & 46 & 346 & 108 \\
\hline 149A & 67.42 & 0.35 & 16.26 & 2.96 & 1.27 & 0.07 & 3.62 & 4.50 & 2.08 & 0.12 & 0.54 & 0.22 & 99.41 & 54 & 555 & 130 \\
\hline $284 \mathrm{~A}$ & 52.62 & 0.50 & 16.91 & 7.92 & 8.13 & 0.13 & 9.14 & 2.22 & 0.91 & 0.10 & 1.76 & 0.16 & 100.50 & 20 & 273 & 52 \\
\hline 51IIA $†$ & 50.33 & 0.27 & 4.33 & 8.45 & 17.34 & 0.17 & 17.05 & 0.50 & 0.18 & 0.04 & 0.26 & 0.10 & 99.04 & b.d. & 48 & 13 \\
\hline \multicolumn{17}{|c|}{ Roof-Zone Dikes } \\
\hline $163 \mathrm{C}$ & 54.33 & 0.94 & 16.76 & 8.77 & 3.81 & 0.15 & 7.55 & 2.66 & 2.53 & 0.43 & & 98.62 & 70 & 506 & 201 \\
\hline 164B & 56.61 & 0.82 & 14.99 & 8.20 & 5.02 & 0.13 & 7.02 & 2.86 & 2.28 & 0.23 & & & 99.15 & 83 & 403 & 122 \\
\hline 548 & 63.68 & 0.50 & 15.65 & 5.53 & 2.76 & 0.10 & 4.92 & 2.99 & 2.45 & 0.15 & \multicolumn{2}{|c|}{$1.01 \ddagger$} & 99.76 & 68 & 407 & 109 \\
\hline 551 & 66.57 & 0.36 & 14.69 & 3.34 & 1.92 & 0.06 & 4.20 & 3.34 & 2.93 & 0.09 & \multicolumn{2}{|c|}{$0.82 \ddagger$} & 98.31 & 62 & 383 & 82 \\
\hline 553 & 58.51 & 0.73 & 15.19 & 7.78 & 4.54 & 0.14 & 7.02 & 2.48 & 2.20 & 0.20 & \multicolumn{2}{|c|}{$1.44 \ddagger$} & 100.22 & 78 & 438 & 121 \\
\hline 554 & 58.57 & 0.73 & 15.39 & 7.48 & 4.67 & 0.13 & 6.80 & 2.83 & 2.26 & 0.20 & \multicolumn{2}{|c|}{$1.17 \ddagger$} & 100.23 & 74 & 445 & 124 \\
\hline 555 & 52.25 & 0.83 & 15.86 & 10.39 & 5.50 & 0.18 & 8.93 & 2.86 & 1.27 & 0.20 & \multicolumn{2}{|c|}{$0.74 \ddagger$} & 99.01 & 42 & 427 & 74 \\
\hline 573 & 56.75 & 0.73 & 16.44 & 7.26 & 3.48 & 0.09 & 7.01 & 2.87 & 2.30 & 0.22 & \multicolumn{2}{|c|}{$1.24 \ddagger$} & 98.39 & 99 & 463 & 120 \\
\hline 590 & 52.51 & 0.59 & 14.72 & 8.89 & 9.18 & 0.16 & 10.17 & 1.54 & 0.31 & 0.09 & \multicolumn{2}{|c|}{$0.93 \ddagger$} & 99.09 & 11 & 245 & 42 \\
\hline \multicolumn{17}{|c|}{ Mafic Microgranitoid Dikes } \\
\hline 188 & 53.45 & 0.73 & 14.82 & 8.93 & 6.94 & 0.15 & 9.29 & 2.45 & 0.90 & 0.18 & 1.14 & 0.25 & 99.24 & 23 & 303 & 78 \\
\hline 192 & 50.14 & 0.73 & 11.29 & 10.22 & 10.67 & 0.18 & 11.96 & 1.40 & 0.39 & 0.23 & 0.87 & 0.32 & 98.41 & b.d. & 230 & 58 \\
\hline 201 & 50.61 & 0.81 & 14.45 & 8.68 & 10.11 & 0.14 & 7.88 & 3.06 & 0.50 & 0.16 & 2.84 & 0.45 & 99.69 & 9 & 374 & 68 \\
\hline 231A & 48.17 & 1.26 & 11.45 & 15.11 & 8.50 & 0.28 & 9.20 & 1.68 & 1.43 & 0.36 & 1.50 & 0.24 & 99.46 & 33 & 177 & 144 \\
\hline \multicolumn{17}{|c|}{ Mafic Enclaves } \\
\hline 122 & 49.84 & 1.11 & 18.10 & 10.62 & 5.35 & 0.17 & 9.39 & 3.00 & 0.83 & 0.29 & 0.57 & 0.17 & 99.44 & 14 & 431 & 50 \\
\hline $135 A$ & 49.85 & 0.83 & 18.36 & 10.15 & 5.50 & 0.17 & 9.76 & 3.26 & 0.69 & 0.19 & 0.85 & 0.18 & 99.81 & 13 & 605 & 69 \\
\hline $154 A$ & 52.60 & 0.73 & 16.10 & 10.20 & 6.52 & 0.20 & 9.57 & 2.84 & 0.89 & 0.21 & 0.85 & 0.17 & 100.89 & 16 & 406 & 61 \\
\hline $154 \mathrm{~B}$ & 50.40 & 0.83 & 14.24 & 10.98 & 8.55 & 0.21 & 10.34 & 2.42 & 0.71 & 0.21 & 0.77 & 0.22 & 99.88 & 10 & 339 & 64 \\
\hline 205 & 44.70 & 1.33 & 16.09 & 12.94 & 8.56 & 0.21 & 12.15 & 1.53 & 0.99 & 0.44 & 1.13 & 0.35 & 100.41 & 14 & 419 & 89 \\
\hline
\end{tabular}

Values are in weight percent; b.d., below detectability.

* Late-stage granite.

+Marginal pyroxenite.

†LOI.

\section{GEOCHEMISTRY}

\section{Introduction}

Table 5 lists representative analyses of the Slinkard pluton, of mafic microgranitoid enclaves and dikes, and of samples from the roof zone. Samples were analyzed at the University of Oregon by $\mathrm{X}$ ray fluorescence techniques. Analytical uncer- tainties are the same as those given by Barnes [1982, 1983]. Two analyses of the WCB from Lanphere et al. [1968] were also included in the data set.

Three chemical trends can be outlined among the coarsegrained plutonic rocks of the WCB/SP system on the basis of the oxide data (Figures 9-11) and petrographic studies. Trend 1 consists of all Slinkard pluton samples and of the structur-

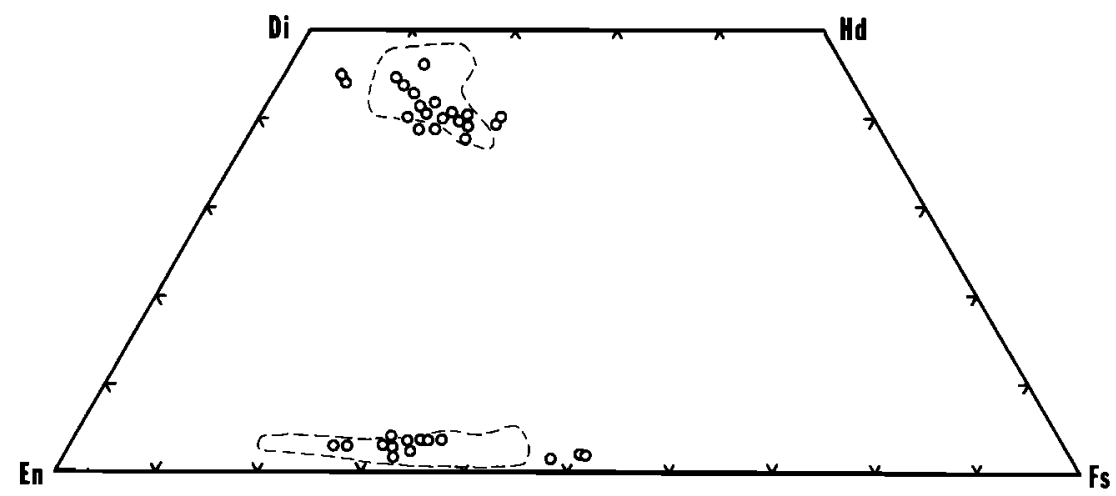

Fig. 7. Pyroxene compositions of roof-zone dikes. Dashed lines enclose range of pyroxene compositions in underlying WCB/SP. Microprobe data from Southern Methodist University and University of Oregon. Fifteen-kilovolt acceleration voltage, 10-na sample current, 10- $\mu$-diameter spot (defocussed for plagioclase). 


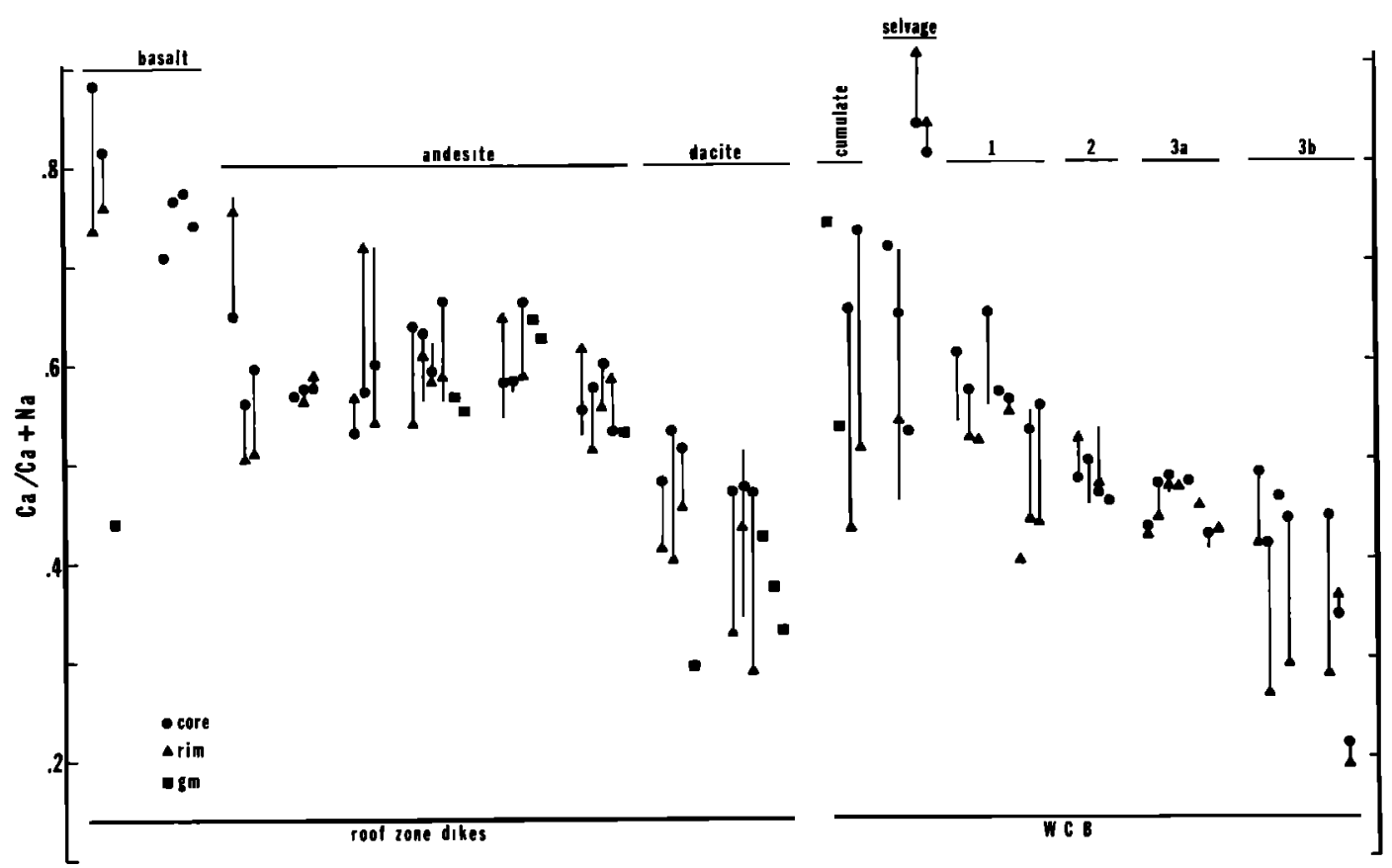

Fig. 8. Anorthite content of plagioclase from roof-zone dikes and WCB/SP. Circles show core compositions, triangles show rim compositions, lines show the range of An content in single crystal. Note common reversed zoning in andesite, normal zoning in other compositions.

ally lowest samples from the Wooley Creek batholith, the northeastern gabbro, diorite, and quartz diorite. Trend 3 samples are from the structurally highest part of the system, the southwestern quartz diorite, tonalite, and granodiorite/granite zones of the Wooley Creek batholith. Trend 2 samples are from scattered localities within the Wooley Creek batholith (samples 103, 236A, 331, 342, 351, 379, and 397 from Barnes [1983]; sample 66CLe 20 from Lanphere et al. [1968]) that are near gradational zones between pyroxene-bearing and pyroxene-free parts of the pluton. Trends 1 and 2 correspond to the pyroxene-bearing rocks and trend 3 to the pyroxenefree rocks of the Wooley Creek batholith [Barnes, 1983].

Roof-zone dike compositions are also shown in Figures 9-11. The scatter in dike compositions could be attributable to accumulation of phenocrysts phases during dike emplacement and to minor hydrothermal alteration. However, the greatest scatter occurs in samples with $\mathrm{CaO}>7.5$ wt \% $\left(\mathrm{SiO}_{2}<54\right.$ wt \%) and is particularly apparent in the plots of $\mathrm{P}_{2} \mathrm{O}_{5}, \mathrm{Zr}$, and $\mathrm{Sr}$ versus $\mathrm{CaO}$ (Figure 11). Zircon crystals and apatite phenocrysts have not been observed in these rocks, and the data of Floyd and Winchester [1975], Winchester and Floyd [1976], and Smith and Smith [1976] suggest that $\mathrm{P}_{2} \mathrm{O}_{5}$ and $\mathrm{Zr}$ should be the least mobile elements during hydrothermal alteration. We conclude that the scatter in this compositional range cannot be adequately explained by crystal accumulation or by alteration.

In general, the most mafic dikes have major element compositions similar to the mafic end-members of trend 1. (Figures 9 and 11 show that the most $\mathrm{Mg}$-rich dike, cpx-rich gabbro, is probably a cumulate.) More evolved dike compositions are similar to trend 3 compositions, except for lower $\mathrm{Al}_{2} \mathrm{O}_{3}$ and $\mathrm{Na}_{2} \mathrm{O}$ abundances. One andesitic sample (163C, Table 5) has much greater $\mathrm{P}_{2} \mathrm{O}_{5}$ and $\mathrm{Zr}$ abundances than similar roof-zone dikes. At present, we have no explanation for these anomalous abundances but note that the dike cuts granodiorite of the Wooley Creek batholith, unlike the majority of analyzed dikes, which are cut by the granodiorite.
Figure 11 also shows compositional ranges of cumulate pyroxenite and gabbro from the WCB/SP and of mafic microgranitoid enclaves and mafic dikes from the interior of the Wooley Creek batholith (Table 5; Barnes [1983]). Too few analyses exist to completely define the compositional range of enclaves and dikes, but preliminary petrographic studies suggest that more felsic enclaves are common. The present data set shows that, with the exception of $\mathrm{P}_{2} \mathrm{O}_{5}$ and $\mathrm{Zr}$, the enclave/dike compositional range includes the mafic endmembers of all three WCB/SP trends (Figure 11).

\section{Discussion}

Previous modeling of the chemical evolution of the system [Barnes, 1983] was based only on compositions of the coarsegrained rocks and their constituent minerals. The early models suggested that the origin of distinct chemical trends within the Wooley Creek batholith was the result of upward enrichment of $\mathrm{H}_{2} \mathrm{O} . \mathrm{H}_{2} \mathrm{O}$ enrichment suppressed plagioclase fractionation in the upper part of the chamber and led to upward enrichment in $\mathrm{Al}_{2} \mathrm{O}_{3}, \mathrm{~K}_{2} \mathrm{O}, \mathrm{Na}_{2} \mathrm{O}$, and $\mathrm{Sr}$. In addition, trace element compositions of the most mafic rocks of trend 3 were best explained by a combination of crystal fractionation and magma mixing. These samples (trend $3 a$ in Figure 9-11) are from the enclave-rich zone of the Wooley Creek batholith and contain evidence of relict pyroxene. The felsic rocks of trend 3 (trend $3 b$ ) show little or no chemical or petrographic evidence of magma mixing; however, major element modeling suggested that evolved trend $3 a$ rocks were the most likely parental compositions for trend $3 b$ rocks [Barnes, 1983]. Thus Trend $3 b$ appeared to have been derived from a magma that had undergone magma mixing.

It is now possible to use the compositions of the cogenetic roof-zone dikes to better understand the evolution of the magma and to estimate the effects of crystal accumulation on the compositions of the plutonic rocks. Figure 12 shows $\mathrm{Sr}$ versus $R b$ variation for the WCB/SP system. Trend 1 samples show considerable scatter but are lower in $\mathrm{Sr}$ than trend 3 


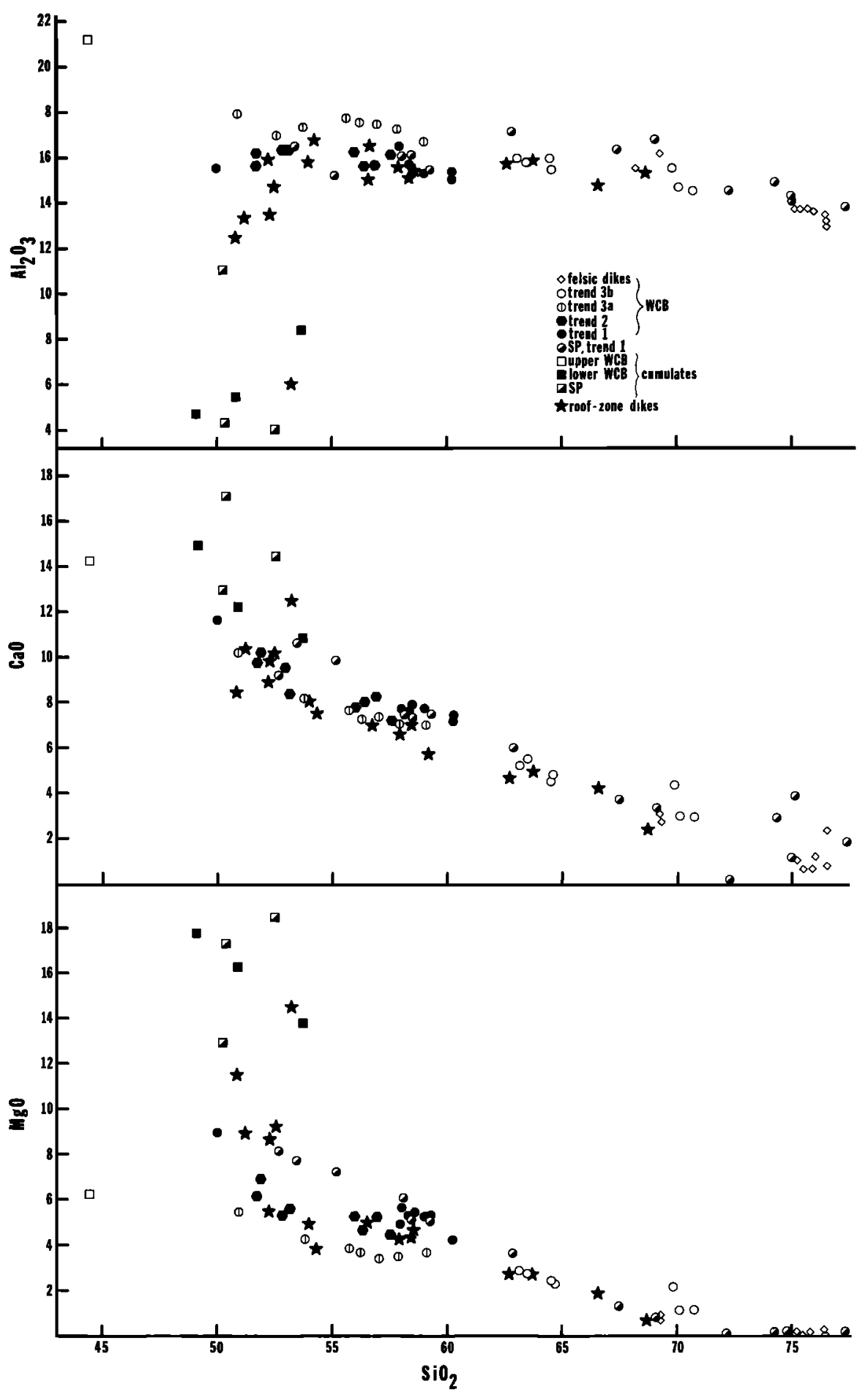

Fig. 9. Major element variation diagrams for WCB/SP plotted against $\mathrm{SiO}_{2}$. See text for further explanation.

samples with similar Rb content. Trend 3 samples show decreasing $\mathrm{Sr}$ with increasing $\mathrm{Rb}$, and trend 2 samples are scattered between the two. In contrast, the roof zone dikes show a broad increase in $\mathrm{Sr}$ with increasing $\mathrm{Rb}$. The solid stars are basaltic and andesitic roof-zone dikes, whereas the open stars are roof-zone dikes of hornblende dacitic compositions. Note that the dacitic dikes are poorer in both $\mathrm{Rb}$ and $\mathrm{Sr}$ (and $\mathrm{Zr}$, Figure 13) than several of the andesitic dikes (Figure 12). Such abundances cannot be explained by fractionation of any combination of phenocryst phases or by crystal accumulation. Yet the close spatial and temporal relations between the andesite, dacite, and underlying pluton (see above) strongly imply a genetic relationship.

The model presented here attempts to relate the roof-zone dike compositions to the three trends displayed by the subjacent coarse-grained rocks. We have concentrated on crystalliquid processes primarily because isotopic data are required to critically evaluate the effects of crustal contamination and melting (research in progress). The most likely source of crustal components are metasedimentary rocks of the eastern Hayfork terrane (Figure 1). Wright [1982] reported detrital zircon from eastern Hayfork sandstone, and one would expect such 


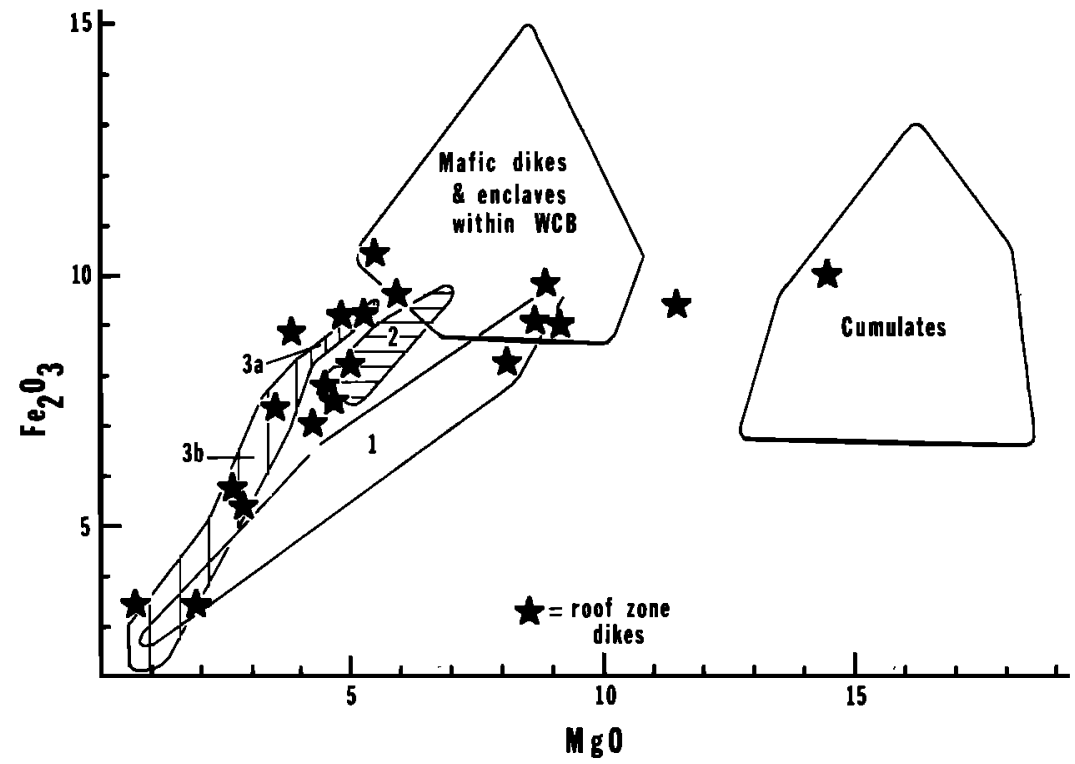

Fig. 10. $\mathrm{Fe}_{2} \mathrm{O}_{3}$ versus $\mathrm{MgO}$. Numbered fields are for trends $1,2,3 a$, and $3 b$ (see text). Compositional fields for mafic microgranitoid enclaves and synplutonic dikes in mixed zone of the Wooley Creek batholith and for WCB/SP cumulates also shown. Roof-zone dikes shown as stars.

zircon to survive assimilation [e.g., Watson, 1979]. No preWCB/SP zircon was recognized in any of the zircon fractions separated for $\mathrm{U}-\mathrm{Pb}$ dating. Note that zircon contamination due to assimilation has been recognized elsewhere in the Klamath Mountains [Saleeby, 1984].

Calculated fractional crystallization and magma mixing models are shown in Figure 12. The solid lines show the variation of $\mathbf{R b}$ and $\mathrm{Sr}$ expected for Rayleigh fractionation in which the bulk distribution coefficient for $\mathrm{Rb}\left(D_{\mathrm{Rb}}\right)=0.01$ and for Sr ranges from 0.6 to 2.0. The dashed lines show expected liquid lines of descent for combined steady state crystal fractionation and magma mixing [DePaolo, 1981], in which the ratio of the mass of fresh magma to the mass of crystals removed is 0.5 and $D_{\mathrm{Sr}}$ ranges from 0.3 to 0.6 . The composition of the mixed magma is the average of four mafic microgranitoid dikes from the WCB (Table 5). We have assumed that all of the evolved rock compositions can be derived from a single parent. In view of the range in composition of mafic microgranitoid dikes and mafic roof-zone dikes (Figures 9-13), this assumption is simplistic, but it serves to illustrate the variety of processes that were active in the WCB/SP system.

Differentiation of the roof-zone dikes can be explained by two mechanisms (Figure 12). The dacitic dikes appear to be the result of simple crystal fractionation, whereas the andesitic compositions are most likely the result of mixing and crystal fractionation. Steady state mixing plus crystal fractionation [DePaolo, 1981] would result in trace element enrichment in the andesitic dikes relative to the dacitic dikes. Mixing can also result in complex, commonly reversed zoning in phenocryst phases [Sakuyama, 1981; Anderson, 1976]. Most plagioclase phenocrysts in the andesitic samples have one or more reversed zones, whereas plagioclase phenocrysts in the dacitic dikes typically show normal zoning (Figure 8).

The roof-zone dike trend provides a convenient dividing line for the discussion of $\mathrm{Sr}$ versus $\mathrm{Rb}$ variations in the coarsegrained rocks of the WCB/SP system (Figure 12). To the right of the dike compositions, trend 1 and trend $3 b$ samples follow curves best explained by Rayleigh fractionation, in which $D_{\mathrm{Sr}}>1$. These rocks lack reversely zoned plagioclase (Figure 8 ), and mafic enclaves are sparse or absent (Figure 2 and
Barnes [1983, Figure 3]), suggesting that mixing was not an important factor. $\mathrm{Rb}$-poor trend 1 samples that lie to the left of the roof-zone dike compositions show considerable scatter. The scatter is probably a reflection of varying proportions of crystal cumulates and trapped liquid [e.g., McCarthy and Hasty, 1976]. Barnes [1983] showed that these rocks are enriched in $\mathrm{Co}, \mathrm{Cr}$, and $\mathrm{Sc}$ and suggested that they were pyroxene-rich cumulate rocks. The $\mathrm{Sr}$ data suggest that at least some of the samples are plagioclase cumulates as well.

Trend $3 a$ rocks also fall to the left of the roof-zone dikes. In terms of Rb-Sr abundances, trend $3 a$ appears to be the result of plagioclase accumulation from a liquid similar to the dacitic dikes in composition (Figure 12). This interpretation is supported by the similarity in plagioclase composition between the dacitic dikes and trend $3 a$ samples (Figure 8). Accumulation of plagioclase and $\mathrm{cpx}$ in trend $3 a$ rocks would also act to drive a dacitic magma toward trend $3 b$ compositions (Figure 12).

Samples from trend 2 plot between trends 1 and 3 in Figure 12. We interpret this pattern to result from simple mixing between late-stage magmas of trends 1 and 3 . This interpretation would explain the intermediate position of trend 2 in plots of $\mathrm{MgO}, \mathrm{Al}_{2} \mathrm{O}_{3}, \mathrm{P}_{2} \mathrm{O}_{5}$, and $\mathrm{Sr}$ (Figures 9-11). Simple mixing near the end of the system's magmatic history would limit the effects of fractionation that would tend to drive the mixed magma toward a cotectic composition.

\section{History OF THE WCB/SP MAGMa Chamber}

The WCB/SP magma chamber began to fill at about 161 $\mathrm{Ma}$. We are still uncertain as to the nature of the initial intrusive event: was it a single pulse of compositionally uniform magma or did the chamber grow slowly as pulses of magma were injected into the crust [e.g., Hildreth, 1981]? The presence of mafic selvages in all structural levels of the system indicates an initial mafic composition. The selvage rocks range from plagioclase-rich cumulates (sample 257, Barnes [1983, Table 7]) to rocks similar to trend 2 samples (66CLe20, Lanphere et al. [1968]) to cpx-phyric rocks similar to mafic roofzone dikes (compare 236A and 555, Table 5 and Barnes [1983, Table 7]). The diversity of mafic compositions and the com- 

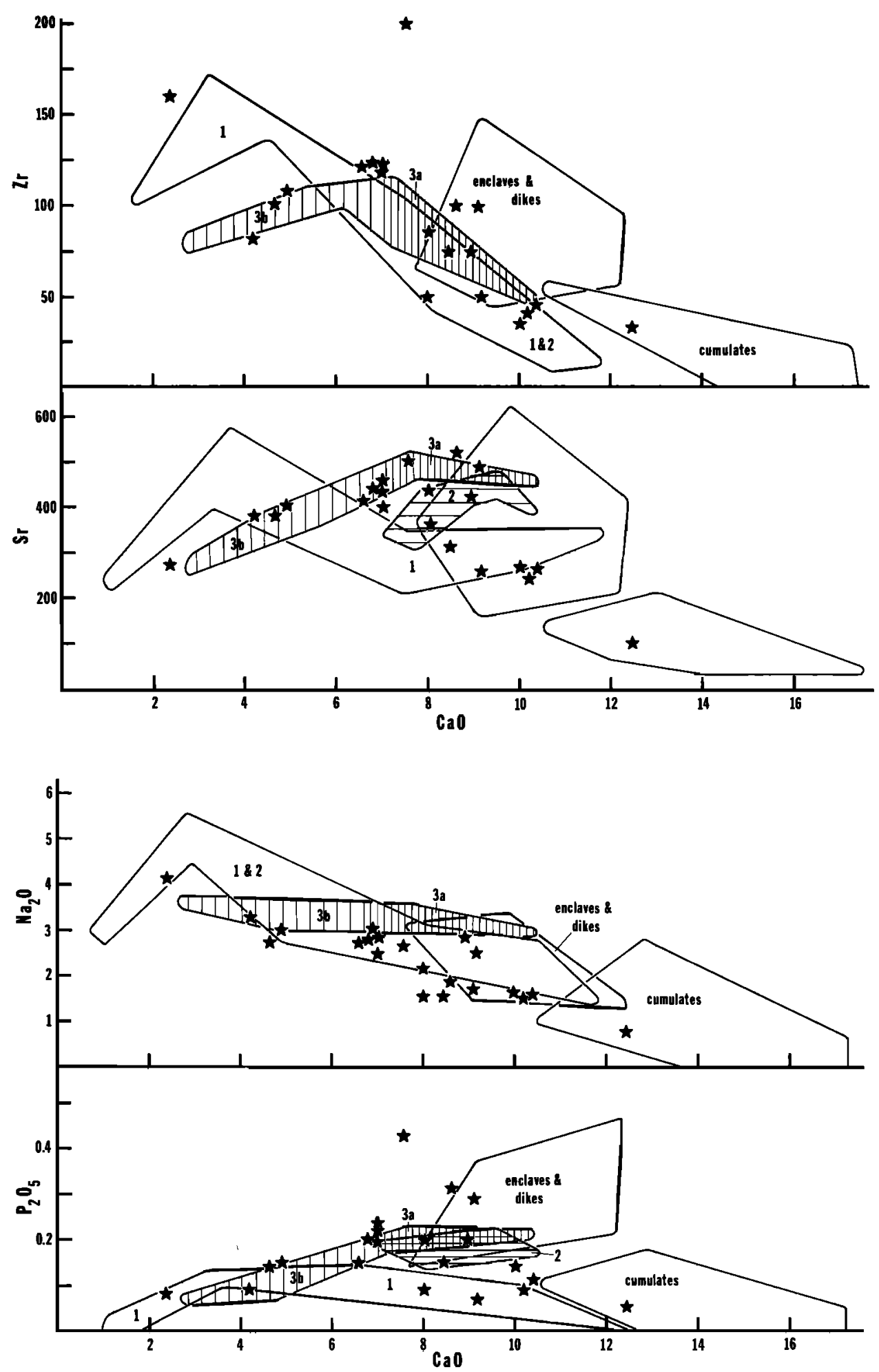

Fig. 11. $\mathrm{Na}_{2} \mathrm{O}, \mathrm{P}_{2} \mathrm{O}_{5}, \mathrm{Zr}$, and $\mathrm{Sr}$ versus $\mathrm{CaO}$. Fields as in Figure 10.

plex cross-cutting relations in the roof zone (Figure 5) support the idea that growth of the chamber was by periodic injections of mafic magma. Certainly, the range of compositions of mafic roof-zone dikes indicates that several mafic compositions were present early in the history of the system.

The southern part of the Wooley Creek batholith has a sill-like shape [Barnes, 1983]. Intrusion of the southern part of the pluton in a southerly direction (present orientation) would have resulted in stretching of the overlying roof rocks. The least principle stress in the roof zone would thus have been parallel to the roof of the pluton and would have been oriented approximately $\mathrm{N} 15 \mathrm{E}$, resulting in the predominant $\mathrm{N} 75 \mathrm{~W}$ strike of roof-zone dikes (Figure $3 a$ ).

Crystal fractionation, probably due to marginal accretion of crystals, resulted in upward flow of $\mathrm{H}_{2} \mathrm{O}$-rich magma, which accumulated in the upper part of the system [Barnes, 1983; 


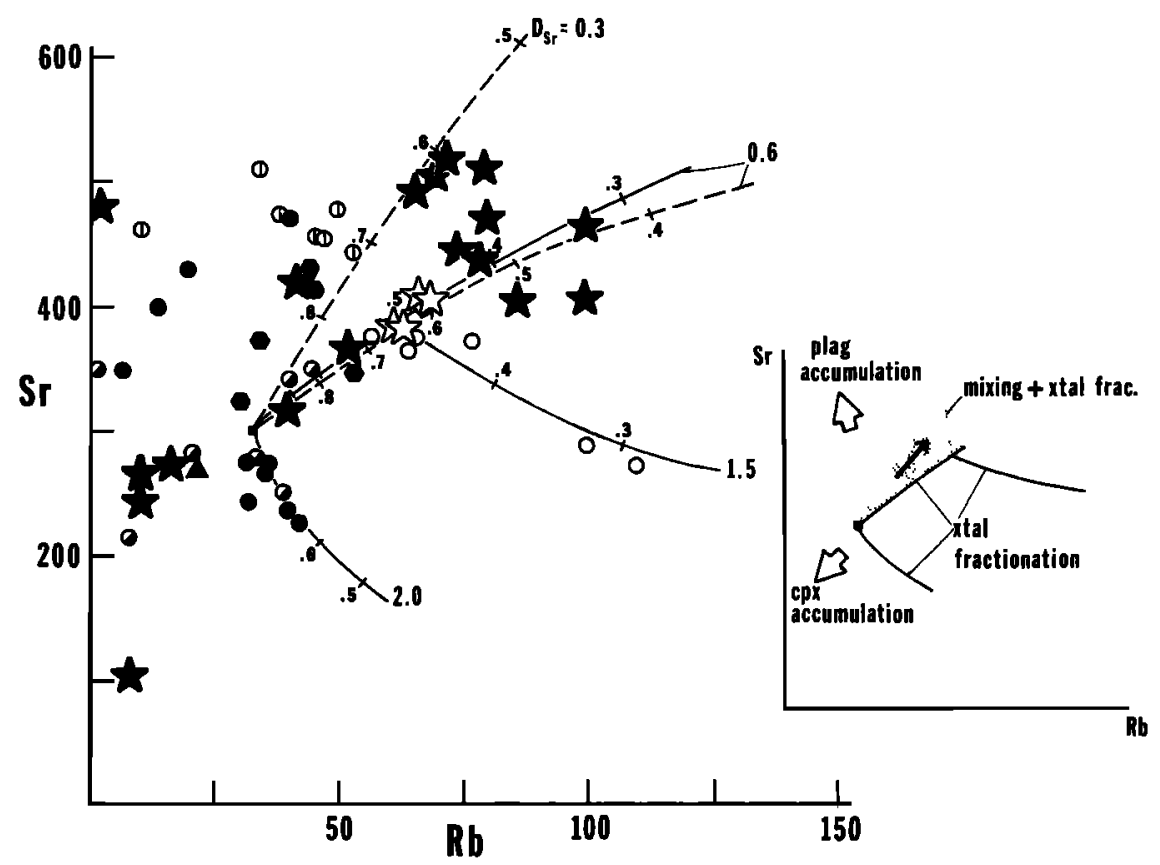

Fig. 12. Sr versus $\mathrm{Rb}$. Symbols as in Figure 9. Open stars are roof-zone dacitic dikes; solid stars are andesitic to basaltic dikes. Triangle is average composition of mafic microgranitoid dikes from the central WCB. Tic marks on curves represent amount of liquid remaining for Rayleigh fractionation (solid lines) and mixing plus crystal frationation (dashed lines) models. Compositions of aplite and pegmatite dikes show wide scatter (due to fluid-phase transfer?) and were not plotted. See text for further explanation.

McBirney, 1980]. Continued injection of mafic magma resulted in combined crystal fractionation and magma mixing in the upper part of the chamber to form trace element enriched andesite now preserved as roof-zone dikes. The lack of evidence of magma mixing in the lower part of the chamber can be explained in two ways: the hot injected basalts rose through the lower part of the system due to their lesser density than the surrounding cooler magma (plume model of Huppert et al. [1984]; also see Turner et al. [1984]), or the source of the mafic input was offset from the center of the base of the system and mafic magma never intersected the lower part of the chamber. Inspection of the cross sections in Figure 2 and Figure 20 of Barnes [1983] shows that we prefer the first interpretation.

As rise of fractionated magma continued, a dacitic cap formed over the zone of mixing. The low density of the cap probably acted as a barrier to newly injected higher density mafic magma. The inability of the mafic magma to rise into the dacitic cap precluded extensive steady state mixing of dacite with basalt and resulted in lower trace element abundances in the dacite relative to the underlying mixed andesite.

Slow cooling of the parts of the plutons not affected by mixing resulted in closed-system fractionation. The upper part of the system evolved toward biotite-hornblende granite (trend $3 b$ ) by crystal fractionation of the dacitic composition (Figure 12). The lower part of the pluton fractionated to tonalite in the WCB and granodiorite/granite in the SP. (The muscovitebiotite granite of the SP is not peraluminous (Table 5) and need not be explained as a crustal melt; however, isotopic data are needed to adequately model the origin of this part of the system.) These closed-system processes left abundant mixtures of crystal cumulates and trapped liquid that are represented by the Rb-poor end-members of trends 1 and 3 .

Following solidification of the upper granodiorite/granite, two-pyroxene and pyroxene-hornblende andesites were intruded from deeper in the chamber. The distinctive texture and restricted (roof zone) occurrence of the pyroxenehornblende andesite suggest a source within the chamber and imply that $\mathrm{H}_{2} \mathrm{O}$-rich magma of intermediate composition was present in the core of the system after solidification of the more siliceous cap. The common occurrence of coarse-grained

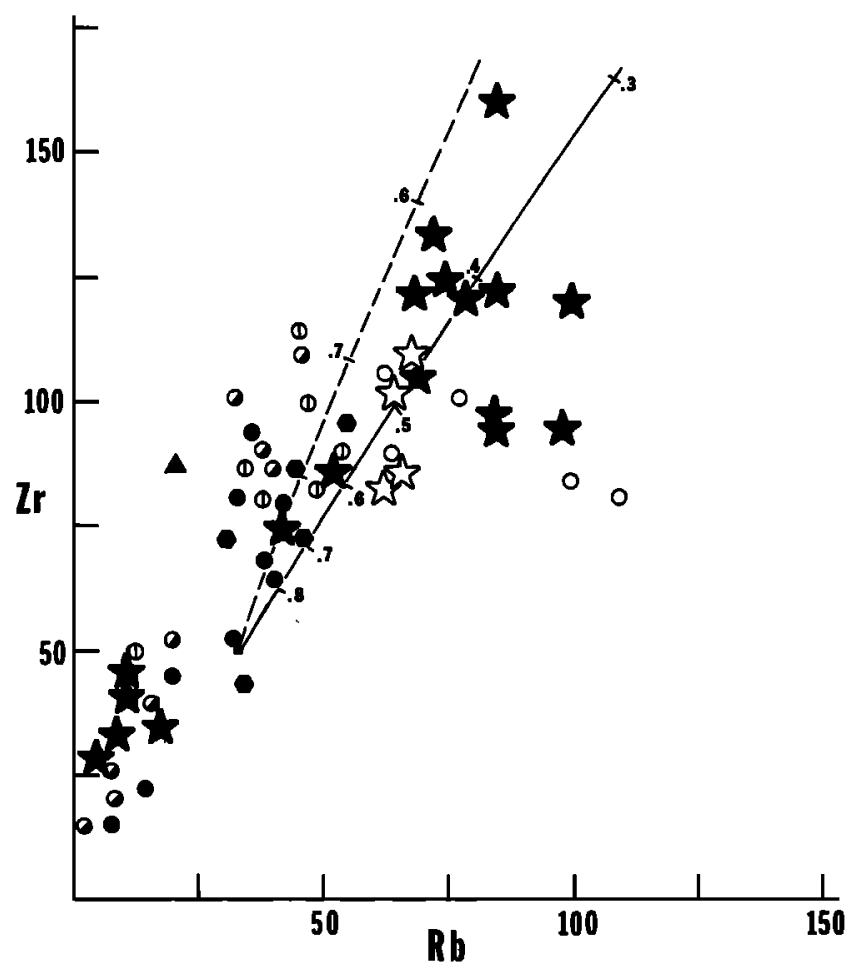

Fig. 13. Zr versus Rb, symbols as in Figures 9 and 12 . Note lower $\mathrm{Zr}$ in dacitic versus andesitic dikes of the roof zone. Solid line for Rayleigh fractionation, dashed line for steady state mixing plus crystal fractionation (see text) where $D_{\mathrm{Rb}}=D_{\mathrm{zr}}=0.01$. 
quartz and biotite xenocrysts in these dikes also indicates that the dike magmas rose through quartz- and biotite-bearing rock or magma.

In the early stages of the system, influx of mafic magma coupled with crystal fractionation apparently resulted in complete mixing to produce the trace element enriched andesitic magmas of the roof-zone dikes. As the system cooled, later mafic input was undercooled and disrupted by flow to form microgranitoid enclaves with oscillatory-zoned plagioclase and acicular apatite. Mixing was accomplished by mechanical disaggregation of the enclaves as opposed to hybridization of two miscible magmas. Such a process probably caused the minor enrichments of $\mathrm{Rb}, \mathrm{Ba}, \mathrm{Zr}, \mathrm{Cr}$, and $\mathrm{Co}$ in trend $3 a$ rocks [Barnes, 1983]. This interpretation is consistent with the abundant mafic enclaves associated with trend $3 a$ samples and with the presence of quartz, hornblende, and plagioclase xenocrysts in mafic enclaves. Magma injected still later formed dikes that were deformed by late flow (Figure 4).

Many lines of evidence indicate that the upper WCB/SP was an open system, with influx of mafic magma, minor influx of differentiated magma from the lower part of the system (northeastern quartz diorite), and upward loss of magma to roof-zone dikes, presumably to the surface. In fact, growth of the magma chamber may have been by gradual addition of mafic magmas. Thus the WCB/SP chamber shows effects of both closed-system fractionation in the Slinkard pluton and lower Wooley Creek batholith and open-system differentiation in the central and upper Wooley Creek batholith.

Acknowledgments. We are grateful to M. A. Kays, R. G. Coleman, and $M$. M. Donato for their encouragement and assistance. Reviews by $A$. Halliday and an anonymous reviewer are greatly appreciated. Our work was supported by NSF grant EAR 8408319 and Texas Tech University (to C. G. B.), Sigma Xi (to C. M. A.), and NSF grants EAR 7925998 and EAR 8206382 (to J. B. S.). Patience and expertise in hand purification of zircon fractions by Cherilyn Saleeby were essential for this study.

\section{REFERENCES}

Allen, C. M., Intrusive relations and petrography of the Slinkard pluton, central Klamath Mountains, California, 120 pp., M.S. Thesis, Univ. of Oreg., Eugene, 1981.

Anderson, A. T., Magma mixing: Petrological process and volcanological tool, J. Volcanol. Geotherm. Res., I, 3-33, 1976.

Barnes, C. G., Geology and petrology of the Wooley Creek batholith, Klamath Mountains, northern California, Ph.D. thesis, Univ. of Oreg., Eugene, 1982.

Barnes, C. G., Petrology and upward zonation of the Wooley Creek batholith, Klamath Mountains, California, J. Petrol., 24, 495-537, 1983.

Barnes, C. G., J. M. Rice, and R. G. Gribble, Tilted plutons in the Klamath Mountains of California and Oregon, J. Geophys. Res., this issue.

Bateman, P. C., and W. J. Nokleberg, Solidification of the Mount Givens granodiorite, Sierra Nevada, California, J. Geol., 86, 563د79, 1978.

Chen, J. H., and G. J. Wasserburg, Isotopic determination of uranium in picomole and subpicomole quantities, Anal. Chem., 53, 20602067, 1981.

DePaolo, D. J., Trace element and isotopic effects of combined wallrock assimilation and fractional crystallization, Earth Planet. Sci. Lett., 53, 189-202, 1981.

Didier, J., Granites and Their Enclaves: The Bearing of Enclaves on the Origin of Granites, 393 pp., Elsevier, New York, 1973.

Donato, M. M., C. G. Barnes, R. G. Coleman, W. G. Ernst, and M. A. Kays, Geologic map of the Marble Mountains wilderness area, U.S. Geol. Surv. Map MF-1452A, 1982.

Floyd, P. A., and J. A. Winchester, Magma type and tectonic setting discrimination using immobile elements, Earth Planet. Sci. Lett., 27, 211-218, 1975.

Hildreth, W., Gradients in silicic magma chambers: Implications for lithospheric magmatism, J. Geophys. Res., 86, 10153-10192, 1981.
Huppert, H. E., R. S. J. Sparks, and J. A. Whitehead, Plumes: Magma chamber replenishment by light inputs, in Proceedings of the ISEM Field Conference on Open Magmatic Systems, edited by M. A. Dungan, T. L. Grove, and W. Hildreth, pp. 83-84, Institute for the Study of Earth and Man, Southern Methodist University, Dallas, Tex., 1984.

Jachens, R. C., C. G. Barnes, and M. M. Donato, Geophysical interpretation of the Marble Mountains wilderness, Siskiyou County, California, U.S. Geol. Surv. Map MF-1452C, in press, 1985.

Jaffey, A. H., K. F. Flynn, L. E. Glendenin, W. C. Bentley, and A. M. Essling, Precision measurement of the half lives and specific activities of ${ }^{235} \mathrm{U}$ and ${ }^{238} \mathrm{U}$, Phys. Rev., C, 4, 1889-1906, 1971.

Krogh, T. E., A low contamination method for hydrothermal decomposition of zircon and extraction of $\mathrm{U}$ and $\mathrm{Pb}$ for isotopic age determinations, Geochim. Cosmochim. Acta, 37, 485-494, 1973.

Krogh, T. E., Improved accuracy of U-Pb zircon ages by the creation of more concordant systems using an air abrasion technique, $G e-$ ochim. Cosmochim. Acta, 46, 637-649, 1982.

Lanphere, M. A., W. P. Irwin, and P. E. Hotz, Isotopic age of the Nevadan orogeny and older plutonic and metamorphic events in the Klamath Mountains, California, Geol. Soc. Am. Bull., 79, 1027 $1052,1968$.

McBirney, A. R., Mixing and unmixing of magmas, J. Volcanol. Geotherm. Res., 7, 357-371, 1980.

McCarthy, T. S., and R. A. Hasty, Trace element distribution patterns and their relationship to the crystallization of granitic melts, $G e$ ochim. Cosmochim. Acta, 40, 1351-1358, 1976.

Mortimer, N., and R. G. Coleman, A Neogene structural dome in the Klamath Mountains, California and Oregon, Geology, 13, 253-256, 1985.

Pitcher, W. S., and M. A. Bussell, Andean dyke swarms: Andesite in synplutonic relationship with tonalite, in Magmatism at a Plate Edge: The Peruvian Andes, edited by W. S. Pitcher, M. P. Atherton, E. J. Cobbing, and R. D. Beckinsale, pp. 102-107, Halsted, New York, 1985

Presnall, D. C., and P. C. Bateman, Fusion relations in the system $\mathrm{NaAlSi}{ }_{3} \mathrm{O}_{8}-\mathrm{CaAl}{ }_{2} \mathrm{Si}_{2} \mathrm{O}_{8}-\mathrm{KAlSi}_{3} \mathrm{O}_{8}-\mathrm{SiO}_{2}-\mathrm{H}_{2} \mathrm{O}$ and generation of granitic magmas in the Sierra Nevada batholith, Geol. Soc. Am. Bull., 84, 3181-3202, 1973.

Rawson, S. A., and S. W. Peterson, Structural and lithologic equivalence of the Rattlesnake Creek terrane and high-grade rocks of the western Paleozoic and Triassic belt, northcentral Klamath Mountains, California, Geol. Soc. Am. Abstr. Programs, 14, 226, 1982.

Reid, J. B., Jr., O. C. Evans, and D. G. Fates, Magma mixing in granitic rocks of the central Sierra Nevada, California, Earth Planet. Sci. Lett., 66, 243-261, 1983.

Roddick, J. A., and J. E. Armstrong, Relict dikes in the coast mountains near Vancouver, B. C., J. Geol., 67, 603-613, 1959.

Sakuyama, M., Petrological study of the Myoko and Kurohime volcanoes, Japan: Crystallization sequence and evidence for magma mixing, J. Petrol., 22, 553-583, 1981.

Saleeby, J. B., $\mathrm{Pb} / \mathrm{U}$ zircon ages from the Rogue River area, western Jurassic belt, Klamath Mountains, Oregon, Geol. Soc. Am. Abstr. Programs, 16, 331, 1984.

Saleeby, J. B., and W. D. Sharp, Chronology of the structural and petrologic development of the southwest Sierra Nevada foothills, California, Geol. Soc. Am. Bull., 91, part II, 1416-1535, 1980.

Saleeby, J. B., G. D. Harper, A. W. Snoke, and W. D. Sharp, Time relations and structural-stratigraphic patterns in ophiolite accretion, west central Klamath Mountains, California, J. Geophys. Res., $87,3831-3848,1982$.

Silver, L. T., The relationship between radioactivity and discordance in zircons, Nuclear Geophysics, Nucl. Sci. Ser. Rep. 38, Nat. Res. Counc. Publ. 1075 , pp. 34 39, National Academy of Sciences, Washington, D. C., 1964.

Smith, R. E., and S. E. Smith, Comments on the use of Ti, Zr, Y, Sr, $\mathrm{K}, \mathbf{P}$, and $\mathrm{Nb}$ in classification of basaltic magmas, Earth Planet. Sci. Lett., 32, 114-120, 1976.

Steiger, R. H., and E. Jager, Subcommission on geochronology: Convention on the use of decay constants in geo- and cosmochronology, Earth Planet. Sci. Lett., 36, 359-362, 1977.

Taylor, W. P., Intrusion and differentiation of granitic magma at a high level in the crust: The Puscao pluton, Lima Province, Peru, $J$. Petrol., 17, 194-218, 1976.

Turner, J. S., H. E. Huppert, and R. S. J. Sparks, The effect of viscosity on mixing in replenished magma chambers, in Proceedings of the ISEM Field Conference on Open Magmatic Systems, edited by M. A. Dungan, T. L. Grove, and W. Hildreth, pp. 160-162, Institute 
for the Study of Earth and Man, Southern Methodist University, Dallas, Tex., 1984.

Vernon, $\mathbf{R}$. H., Restite, xenoliths and microgranitoid enclaves in granites, J. Proc. R. Soc. N. S. Wales, 116, 77-103, 1983.

Wagner, D. L., and J. S. Saucedo, Geologic map of the Weed quadrangle, California, Regional Geol. Map Ser., Map 4A, scale $1: 250,000$, Calif. Div. of Mines and Geol., in press, 1985.

Watson, E. B., Zircon saturation in felsic liquids: Experimental results and applications to trace element geochemistry, Contrib. Mineral. Petrol., 70, 407-419, 1979.

Wetherill, G. W., Discordant uranium-lead ages, I, Eos Trans. AGU, $37,320-326,1956$.

White, A. J. R., and B. W. Chappell, Ultrametamorphism and granitoid genesis, Tectonophysics, 43, 7-22, 1977.

Wiebe, R. A., Comingling of contrasted magmas in the plutonic environment: Examples from the Nain anorthositic complex, J. Geol., $88,197-209,1980$.

Wiebe, R. A., A stratigraphic record of magma mixing and liquid evolution in the Newark Island layered intrusion, Nain, Laborador, in Proceedings of the ISEM Field Conference on Open Magmatic Systems, edited by M. A. Dungan, T. L. Grove, and W. Hildreth, pp. 166-168, Institute for the Study of Earth and Man, Southern Methodist University, Dallas, Tex., 1984.
Winchester, J. A., and P. A. Floyd, Geochemical magma type discrimination: Application to altered and metamorphosed basic igneous rocks, Earth Planet. Sci. Lett., 28, 459-469, 1976

Wright, J. E., Permo-Triassic accretionary subduction complex, southwestern Klamath Mountains, northern California, J. Geophys. Res., 87, 3805-3818, 1982.

Zen, E.-A., Implications of magmatic epidote-bearing plutons on crustal evolution in the accreted terranes of northwestern North America, Geol., 13, 266-269, 1985.

Zen, E.-A., and J. M. Hammarstrom, Magmatic epidote and its petrologic significance, Geol., 12, 515-518, 1984.

C. M. Allen, Department of Geological Sciences, Virginia Polytechnic Institute and State University, Blacksburg, VA 24061.

C. G. Barnes, Department of Geosciences, Texas Tech University, Lubbock, TX 79409.

J. B. Saleeby, Division of Geological and Planetary Sciences, California Institute of Technology, Pasadena, CA 91125.

(Received November 12, 1984;

revised October 1, 1985;

accepted October 7, 1985.) 